\title{
4 Epictetus and the idea of a human calling based on human reason
}

In this chapter, we seek to demonstrate that and how key passages in Epictetus offer the best parallel for understanding Paul's use of reason language in Rom 12.1. We will show that Epictetus 1.16 offers one of the clearest instances of the notion of a human vocation and how it is linked to reason language (入оуıкóৎ). ${ }^{1}$ Usually only Epictetus 1.16 .20 is quoted as a parallel, ${ }^{2}$ but we argue that Epictetus 1.16.20 - 21 should be considered to be the parallel. And this passage should not be considered in isolation, but as the climax of the entire preceding Discourse. For this reason, we offer an exegesis of the entire Discourse to show how the themes discussed by Epictetus build up towards that climax. This will also allow us to draw out the ways in which Epictetus retrieves themes from the broader ancient discourse on what it means to be human.

In this chapter we will also discuss Epictetus 2.9 and Epictetus 1.6 in detail. This is because Epictetus 2.9 is an excellent example of how the definition of

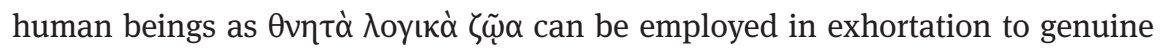
humanness. Epictetus 1.6 is another instance in which $\lambda$ oyıкó language is used. Once more the idea of a human vocation is key to the Discourse. Already in Epictetus 1.16 one can detect that there is a certain structure to the human vocation, but Epictetus 1.6 makes this structure explicit and shows that it is a sign production based on insight into God's relation to the world.

The main topic of Epictetus 1.6 and Epictetus 1.16 is divine providence, how humans can recognise it and what they should do based on this recognition. ${ }^{3} \mathrm{Be}-$ cause divine providence, as insight into God's relation to the world, is central to Epictetus' view of the human vocation, we will analyse two passages (Epictetus 1.12 and 4.7) in which divine providence figures prominently before we come to the discussions of Epictetus 1.6 and 1.16.

The outline of this chapter is as follows. We will begin by contextualising Epictetus, discussing the manner in which we are comparing Paul and Epictetus (section 4.1); our main point is that Epictetus, even though later than Paul, offers

1 As in previous chapters, except where it could be misleading, we refer to his Discourses (Diatribai or Dissertationes) simply by the numbering following the text of Schenkl 1916 (thus Epictetus 1.16 stands for Epictetus, Diatr. 1.16). The Greek text cited is Schenkl 1916.

2 Byrne 1996, 366 is an exception.

3 On the importance of the topic of divine providence in philosophical discussion at Rome see Niehoff 2018, 75, who shows that Philo's stay in Rome moved him towards a more Stoic philosophical position (74), not least on the issue of divine providence (74-77).

Ә OpenAccess. (c) 2021 Simon Dürr, published by De Gruyter. (cc) BY-NC-ND This work is licensed under the Creative Commons Attribution-NonCommercial-NoDerivatives 4.0 International License. 
the best articulation of a broader ancient tradition with which Paul is familiar and with which he interacts. Then we will discuss the first part of Epictetus 2.9 to show how he talks about genuine humanness based on the definition of human beings (section 4.2). Next, we will establish the importance of divine providence for Epictetus' conception of the human calling (section 4.3), as a preparation for the exegesis of Epictetus 1.16 (section 4.4) and the exegesis of the first part of Epictetus 1.6 (section 4.5).

\subsection{Epictetus in his context and in comparisons with Paul}

In this section, we provide some historical context for Epictetus and establish how we are comparing Paul to Epictetus. ${ }^{4}$ Epictetus is the most important ancient dialogue partner for Paul when it comes to the connection between the human endowment with reason and the calling of human beings in the world in which they are placed. He is our most important source for an explicit connec-

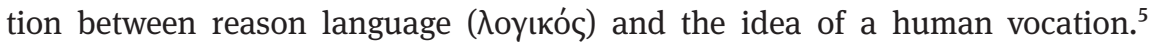

4 A very useful discussion of various models for ways in which Paul and Epictetus have been compared is provided by Vollenweider 2013, section 2.

5 Epictetus - like Socrates - has left nothing in writing, but in Arrian's recordings of his teaching scholars see an accurate and faithful rendering of the dialogues and teaching conversations of Epictetus himself. This is because when Arrian writes in his own voice (for instance on Alexander's conquest) he uses a completely different style looking back to Attica, while in the Discourses we find a language so strikingly reminiscent of the Pauline koine, that scholars could not fail to detect in both the common features of the diatribe style. In the Discourses, Arrian seems to record actual teaching discourses of Epictetus; in the Enchiridion, Arrian summarises the contents of the Discourses. Because of this, one of the leading current scholars on Epictetus, A.A. Long, attributes more source value to the Discourses than to the Enchiridion, valuable though both are (cf. Long 2002). C.K. Rowe disagrees (2016) but his reasons are unconvincing: the fact that both are written down by Arrian does not make them equal. Though only four of probably eight books of the Discourses have been preserved, we can be confident that the missing texts would not substantially alter the picture we get of Epictetus' philosophy. This is because of his repetitive style, which makes him repeat important points in different metaphorical garb. That such repetitions serve a psychagogic function is missed already by ancient critics (e.g. Quintilian on Seneca).

The term diatribe is problematic. As a genre designation it is not useful. Bultmann 1910 has been influential. On the topic see Stowers 1981 and Schmeller 1987 (cf. also his article in the EBR); cf. also Wright 2013, 224. Long objects to the use of "diatribe" to designate a genre and would prefer an approach to the "so-called diatribe tradition" that would recognise it as a "practice, both oral and written, of ethical training to which professional teachers and didactic writers contributed in ways that were both generic and individual" $(2002,49)$. 
There is no question of literary dependence between Epictetus and Paul: ${ }^{6}$ rather Epictetus brings to clearest and explicit expression ideas with a wider currency in the ancient cultural encyclopedia. ${ }^{7}$ Above all, it is the content of Epictetus' teaching which has impressed the readers of the Discourses with its ethical vision and this has always invited comparison with Paul. ${ }^{8}$

One of the most important texts of Epictetus for this study, Discourse 1.16, is both among the purple passages of Epictetus scholars, ${ }^{9}$ or of Greek philology in general, ${ }^{10}$ and one of the most frequently cited parallels for Rom 12.1. ${ }^{11}$ But these

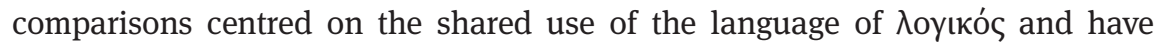
mostly seen the topic of worship in both Rom 12.1 and Epictetus 1.16. They have not considered the parallel with a view to the connection, among the philosophers, between the human endowment with reason and the human vocation. Thus they have missed the fuller pragmatic import of both passages: there is a protreptic or exhortative function not just in Epictetus but also in Paul. They have also missed the larger cultural, philosophical, and anthropolog-

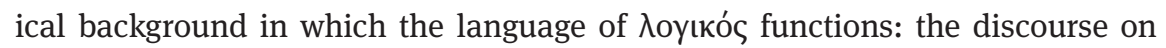
what it means to be human. Ancient discussions about the nature of human beings embedded in a cosmos of meaning always raise normative claims as well as they seek to describe what human beings are (in their cultural encyclopedia). Because of this normative dimension, such statements are particularly suitable for protreptic discourse $\mathrm{e}^{12}$ and thus precisely for what Paul is doing in Rom 12.1-2:

6 Epictetus is born sometime around AD 50 in Hierapolis in Phrygia, peaked with his philosophical teaching in the time of Trajan, and died around AD 125, so Paul cannot have known his teaching. While Zahn 1895 had attempted to show that Epictetus was dependent on Christian tradition, scholars since Bonhöffer 1911 are agreed that Epictetus was not directly influenced by early Christian views (cf. Long 2002, 35).

7 As can be seen from the material we have presented in section 2.2 and chapter 3 .

8 For Bonhöffer, for instance, Epictetus, among ancient writers, is the one who is closest to early Christianity in terms of the ethical and religious content of his philosophy (1911, 2). For a recent comparison of Paul and Epictetus with regards to ethics cf. Schnelle 2009. Other thematic comparisons focus on the concept of law (so Huttunen 2009) or the notion of person (so Eastman 2017, 29-62).

9 Cf. the quotation of Epictetus 1.16.20 - 21 at the beginning of the first chapter in Long 2002. 10 Cf. its inclusion in the anthology of Wilamowitz-Moellendorf 1902, 1.236-7 and 2.202-3. 11 E. g. Lietzmann, Cranfield, Dunn, Wright, Thorsteinsson, Wolter.

12 Such as we find in Aristotle's Protrepticus (as we can reconstruct it from Iamblichus among others, see section 3.2.1). Sorabji (1993, 15 n. 46) doubts the ascription. A useful definition is "Protreptics ... refers to a literary genre which attempts to persuade the reader of the value of a subject of study and seeks to enthuse him and convince him to 'turn' to it” (DNP, s.v. "Protreptik"), if we broaden it to be a textual function (not just a genre) and if it can refer to the adoption of a way of life, and not merely the study of a subject. Cf. also Berger 1984, 1138-1145. 
framing in an inviting manner his own vision of the integrated existence of Jesusfollowers. Paul does this in ways that resonate with the ancient anthropological discourse. This contextualisation is needed for a full explanation of Paul's use of reason language.

Epictetus is an important parallel, because he brings to a particularly clear expression anthropological views that many philosophers and indeed much of Greco-Roman culture would have shared. Much of it belongs to the then current Greco-Roman cultural encyclopedia and forms a common stock of ideas and images. As such it would have been familiar to both Paul and his readers. ${ }^{13}$ But just as Epictetus is both an exponent of established Stoic doctrine, expressive of wider cultural currents, interacting with other schools, ${ }^{14}$ and original, ${ }^{15}$ so also Paul, we argue, has drawn on cultural and philosophical discussions about genuine humanness and the human calling, and yet has said something decidedly new. But to understand him at this point, the modern interpreter needs to be attuned to this common stock of anthropological assumptions.

The following points can be cited as support for the claim that ancient philosophy also held views that enjoyed wider cultural acceptance. First, because

13 Cf. Schnelle 2016, 45: "Fast allen Mitgliedern frühchristlicher Gemeinden in Städten wie Ephesus, Korinth, Philippi, Athen, Rom dürften die philosophischen Hauptströmungen der Zeit (zumindest in rudimentärer Form) bekannt gewesen sein”.

14 Epictetus interacts with the Platonic tradition, less with Aristotle's writings, is sympathetic to but not part of Cynicism (cf. Epictetus 3.22), and outrightly rejects Epicureanism. Epictetus responds and relates to other philosophical currents of his day. A. A. Long has renewed scholarly attention to the importance of the Socratic tradition for Epictetus, whose favourite among Plato's early dialogues seems to have been the Gorgias (see Long 2002, ch. 3). On the debate about philosophical "eclecticism", reinvigorated with Dillon and Long 1988, see especially ch. 1 on the history of the concept. In any case: the schools had their notable differences, but should not be seen as living in closed compartments. It seems probable that they would have been known for certain distinctive viewpoints by a general audience (an example would be the link between Epicurus and $\dot{\eta} \delta o v \eta ́)$. In some contexts, the differences between the schools would not matter and they might well be put together as just the philosophers. Engberg-Pedersen 2017 seeks to forge ahead with a useful classification of the complex relations among philosophical strands around from $100 \mathrm{BC}$ to $\mathrm{AD} 100$.

15 Bonhöffer $(1890$; 1894) has treated the question of Epictetus' relation to earlier Stoicism extensively. He argues $(1890, v)$ that Epictetus is an excellent source for early Stoicism on all topics of interest to him. Later scholars find Bonhöffer putting too much emphasis on continuity and downplaying originality (e.g. Long 2002, 66, 93; cf. the criticism of Jagu 1946, 120-122). Current scholarship sees him as being close to early Stoic views in many points, yet innovative in others: the doctrine of the three topoi (cf. Epictetus 1.4, 3.2) is new, for example. It is his answer to the question in which sequence the three parts of philosophy - logic, physics, and ethics - should

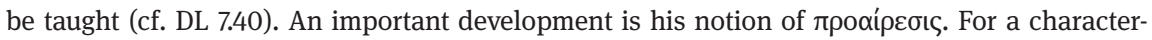
isation of Epictetus as a "more independent thinker and educator" see Long 2002, 92. 
ancient philosophy had cultural prestige, their views would have been of interest to many people. ${ }^{16}$ Second, the philosophical schools were ways of 1 life ${ }^{17}$ and their topics such as any person with basic education could engage with; ${ }^{18}$ and though they held positions that are counterintuitive, they also appealed to common

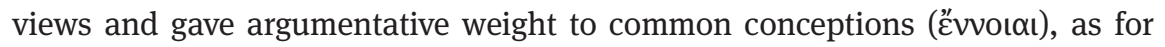
instance the Stoics in Cicero's De natura deorum. ${ }^{19}$ Thus, straying too far from common sense on some points would have made little sense for them. They also appealed to general experience, on which they sometimes based their protreptic appeals. Philosophers did hold counter-intuitive positions. ${ }^{20}$ In such cases, they might explain the deviation from common sense with an appeal to the befuddlement of the masses that made them miss the truth. But in large measure their basic assumptions about human beings would be broadly shared by wider Hellenistic tradition.

In order to bring out this broader discursive context, our method aims to attend to the larger discursive frame of those texts that are used as parallels. In comparative studies, it is a common place to emphasise that the relata are both to be treated with sensitivity to their own context, setting, genre, pragmatic situation and so on. But attention to wider discourses is sometimes required, and the following readings of Epictetus attempt to do this with regard to the traditions we have already outlined in chapter 3.

To serve this aim, we have chosen the form of something like a running commentary. ${ }^{21}$ When we quote texts in extenso it is for the purpose of close comparison. For the quotations we have used Robin Hard's excellent translation. ${ }^{22}$ We seek to note thematic overlaps which gain importance through the interconnections they establish among the particular comparanda, which is often missed by those comparisons for which Sandmel's charge of "parallelomania” may be justified. $^{23}$

16 The relatively meagre impact of institutional philosophy today on how people live might offer a misleading parallel, on which see Schnelle 2016, 21 and Wright 2013, 204.

17 On this theme, see especially Hadot 1995. Rowe (2016) bases much of his argument upon the work of Hadot, but seems to overemphasise the incommensurability between different ways of life and the radical non-intelligibility supposedly bound up with "rival traditions". In critical interaction with Hadot, while still granting the overall point, are Horn 2014 and Cooper 2012.

18 Cf. Wright 2013, ch. 3.

19 Cf. also Epictetus on preconceptions which assure good choice in ethics.

20 Not least in the famous Stoic paradoxes: only the wise man is rich and so on.

21 For an actual commentary, see Dobbin 1998.

22 Hard 2014. It is slightly paraphrastic, but often in a manner that brings out contextual nuances. At some points, we point out more literal renderings.

23 Sandmel 1962. 
With these remarks, we turn to the first text analysis.

\subsection{The definition of human beings and genuine humanness in Epictetus 2.9}

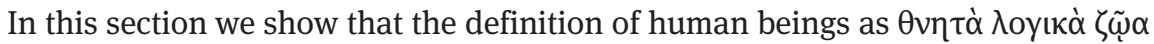
can be used to speak about being human in a normative sense, to develop an appeal to genuine humanness. ${ }^{24}$ In Epictetus 2.9, the fulfilment of the ethical aspiration that goes with human being in the normative sense is discussed and derived from the very definition of human beings. Robin Hard's translation of the title of the Discourse is suggestive for our terminology of human vocation or calling: "That although we are unable to fulfil our human calling (

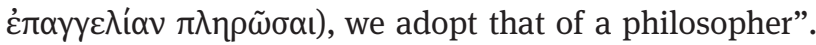

The idea of genuine humanness (or of a human vocation) is expressed in different language in the source texts. ${ }^{25}$ Here the word 'ं $\pi \alpha y \gamma \varepsilon \lambda i ́ \alpha$ has interesting resonances with both genuine humanness and a human vocation. The word

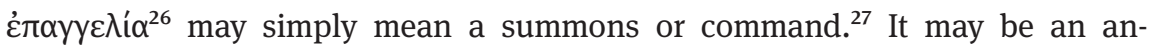
nouncement of an event (such as of a sporting competition) or a "summons to attend" at an assembly. It can also be used more broadly for an "offer" or "promise" of something, ${ }^{28}$ possibly as the reason which might attract people to follow the "summons". At this point, the promise verges closely on the language of advertisement (when professionals speak about what they can offer ${ }^{29}$ ). It appears in

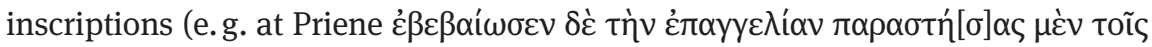

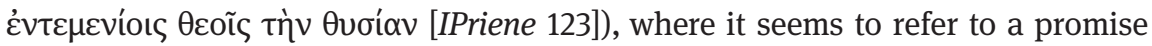
made to the gods of the shrine, which were fulfilled by offering sacrifices. ${ }^{30}$ But it

24 Cf. also section 2.2.6.

25 As we have seen in section 3.2.

26 We here summarise LSJ's examples.

27 Somebody sends a messenger with a request for something to someone else, e.g. at Polybius 9.38.2, when the Persian great king Xerxes demands "water" and "earth" (i.e. complete submission on both land and sea) from the Spartans and they "heroically" appeal to Greek liberty and reply with a mock performance based on a literal interpretation of the demand.

28 Epictetus 1.4.3 uses it in this sense for instance for the "promise of virtue". Paul uses the

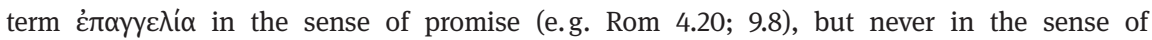
"human vocation" as Epictetus does in 2.9. This is not a problem for our interpretation, however, as we noted in section 1.4. There are different linguistic resources to speak about the human role in the cosmos (see section 3.2).

29 E. g. in discussion of the advance payment of Sophistic teachers at Aristotle, EN 1164a 29.

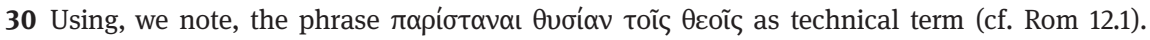


can also mean "profession" or "undertaking", either for a concrete job to perform, or more generally, as that which one might reasonably expect the cobbler to achieve as a matter of his professional occupation. It can also be used for political canvassing, or, in medical contexts, to express the curative properties

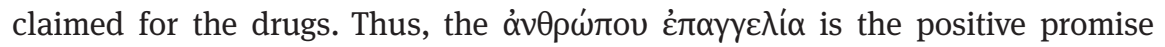
that comes with a human being (in case the person lives up to genuine humanness). ${ }^{31}$ It is that which one should be able to expect from a human being one encounters. But it has a nuance of the human "profession" (as a metaphor), or the human role or calling. ${ }^{32}$ Having said this, we may now consider the first part of Epictetus 2.9:

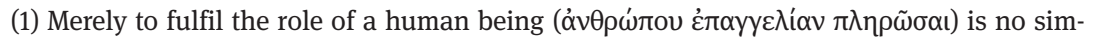

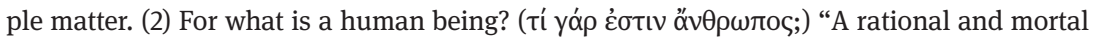

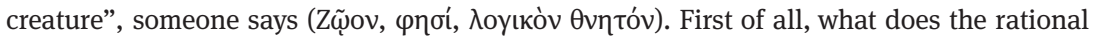

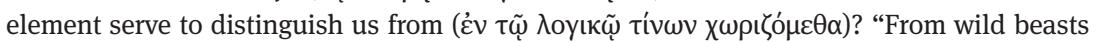

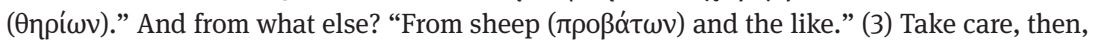

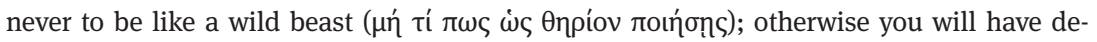

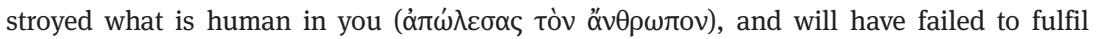

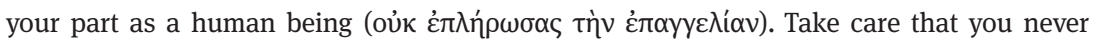

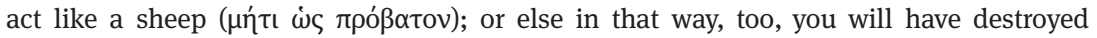

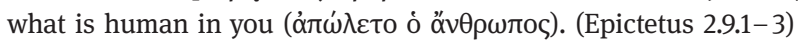

This is a clear expression of a genuine humanness, which is based on the definition of human beings and especially the distinctive feature, the endowment

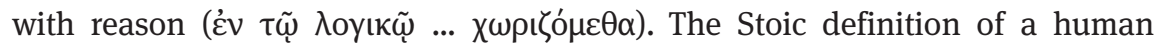
being can simply be presupposed here ("someone says" - Epictetus and his "diatribal" interlocutor can proceed from this shared base). The definition is then explicated with a view to its ethical import (which is not, for the ancients generally, a projection upon nature, but a raising to explicit awareness of what is

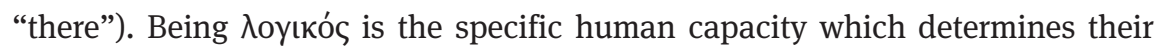
particular purpose and determines what genuine humanness means. The contrast is provided by animals which lack reason and the types of behaviour which are associated with them. What seems to be in view here is the employ-

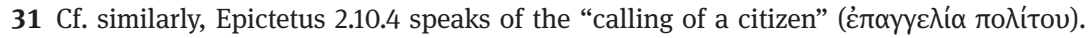

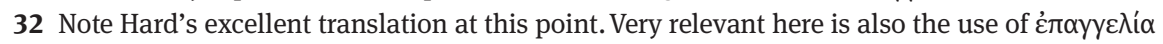

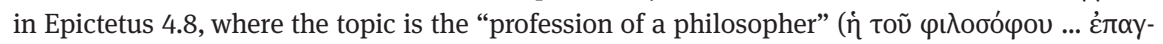

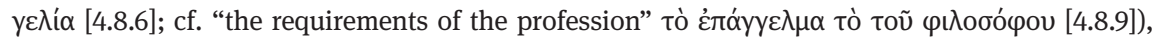
contrasted with the carpenter and the musician (4.8.4), and that it should not be evaluated by outward appearance (using a carpenter's axe, singing, long hair and a cloak as indicators

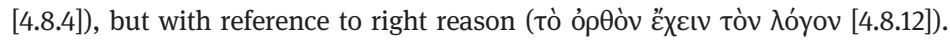


ment of reason to exercise control over the emotions. ${ }^{33}$ If you behave like a beast - as, say, tyrants are wont to $\mathrm{do}^{34}$ - you destroy what is human in you and you do not fulfil the promise or calling of your human nature. ${ }^{35}$ The term "human" is here used in an axiologically charged or ethically normative sense. As such it admits of degrees: humans can behave more, or indeed less, in accordance with the promise of their nature, and perhaps even lose their humanness in this ethical sense. By contrast, in the sense of belonging to a class, the term "human" does not admit of degrees. ${ }^{36}$ The definition of what humans are with reference to reason serves to support an ethical point, or rather one of "vocation". While the examples that follow do focus on morality, they are nevertheless conceived as something that is appropriate for the being that one is and as a condition for the fulfilment of one's purpose within a larger cosmos. And because of this, it is appropriate to identify them as being about genuine humanness.

Epictetus goes on to develop the theme of genuine humanness by explaining what he means with these contrasts to animals:

\begin{abstract}
"When is it, then, that we act like sheep ( $\dot{\omega} \varsigma$ лрó $\beta \alpha \tau \alpha)$ ?” When we act for the sake of our

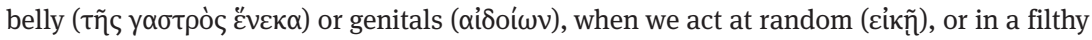

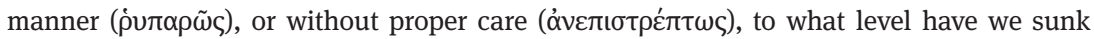

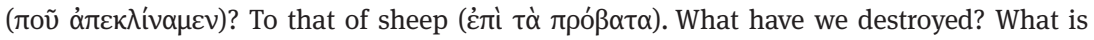

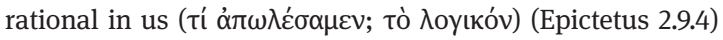

The first example is sheep-like behaviour. Comparisons with animals for ethical discourse are nothing surprising. ${ }^{37}$ Epictetus can also use sheep in positive comparisons, ${ }^{38}$ but here they are used stereotypically to characterise "sub-human" behaviour. Epictetus presumably thinks of excessive behaviour and does not mean to imply criticism of the behaviour of Cynic philosophers, who might have been more comfortable with following the immediate promptings of the

33 Cf. the self-mastery reading of Romans by Stowers 1994, who rightly recognises this theme in ancient ethical discourse, but probably overestimates its centrality to the argument of Romans. Cf. also 4 Maccabees' exposition on that theme applied to Jewish heroes such as Eleazar.

34 Cf. for instance Plato, Resp. 566a.

35 Cf. also the Latin development in which humanitas is becoming a synonym for clementia (e.g. Seneca, Ira 1).

36 For this sense, which remains the same for human beings, see for instance Aristotle, Cate-

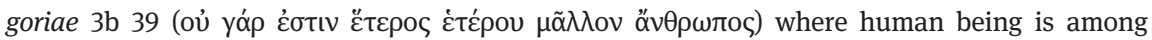
the main examples for substance (ov̉oía) and this point is made as explication of the principle

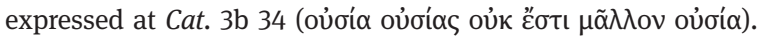

37 On animals in ethical comparisons see Dierauer 1977. The narrative traditions associated with Aesop furnish many examples.

38 E.g. Epictetus 1.23.7. 
body than polite custom would have thought proper. ${ }^{39}$ We note in passing that the first two brush-strokes of his portrait of what he sees as "sub-human" behav-

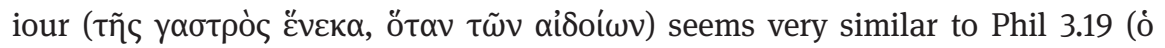

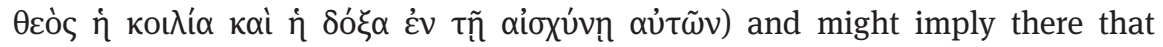
Paul characterises his "opponents" as failing precisely in the genuine humanness which Paul claims as aspiration for his communities. Implicit in this list, however, is not just a control of the "baser instincts", but also something like "table-manners" and purposeful living (not "just so" [عikñ]). And we note in particular that the reply to the question of what has been destroyed ( $\tau^{\prime} \dot{\alpha} \pi \omega \lambda \varepsilon \dot{\varepsilon} \sigma \alpha \mu \varepsilon v$ )

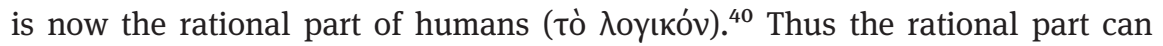
here stand in the same place as human being as the object that is "destroyed"

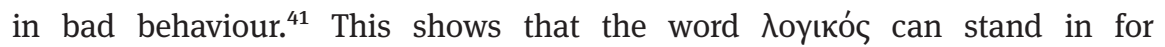
"human" in the normative sense. ${ }^{42}$ Thus this passage confirms that the language of $\lambda$ oyıкó can be used in a sense that does not merely classify human beings or reduce them to their distinctive rationality; rather it serves to describe here, not least in a context where the audience is "exhorted" (protreptic discourse, broadly understood), what genuine humanness entails and how it is tied to an idea of human vocation. More than semantic analysis is needed to pick up on these connections. For the second example, Epictetus moves up from what Plato might

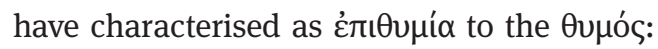

And when we behave aggressively ( $\mu \alpha \chi \dot{\prime} \mu \omega \varsigma)$, and harmfully ( $\beta \lambda \alpha \beta \varepsilon \rho \tilde{\omega} \varsigma)$, and angrily $(\theta v \mu \mathrm{-}$

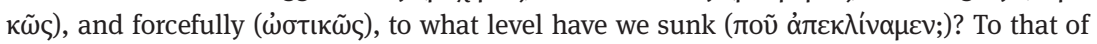

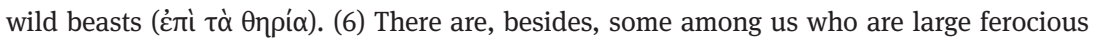

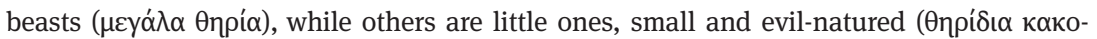
$\eta \dot{\eta} \theta \eta$, which prompt us to say, "I'd rather be eaten by a lion $(\lambda \varepsilon \dot{\varepsilon} \omega v)$ !" (7) By all such behav-

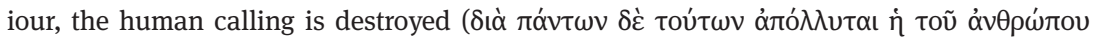

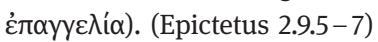

The wild beasts, both the lion and other smaller animals of the ferocious kind, serve to illustrate aggression and anger. There are many ways in which one can

39 Cf. Epictetus 3.22 on the ideal Cynic.

40 This is another feature that seems to indicate that Epictetus is here close to Plato's ideas in the Respublica or the traditions associated with it.

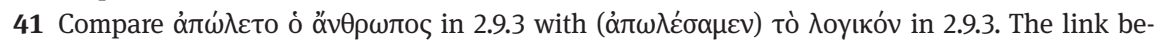

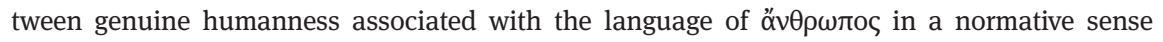
and the human vocation becomes apparent when the third object of what is destroyed in bad

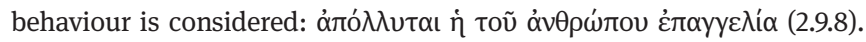

42 Against Scott 2018, 505-506, who only considers the classificatory sense of being human. 
fail to live up to the human calling (2.9.7), as the differences between the large

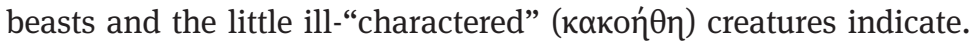

The passage also strongly resonates with Platonic tradition, especially Resp. 588b-589d (which we have discussed in section 3.1.7), where the appetitive part was likened to a "beast" (Onpíov), the spirited part to a "lion" ( $\lambda \dot{\varepsilon} \omega \nu)$, while the

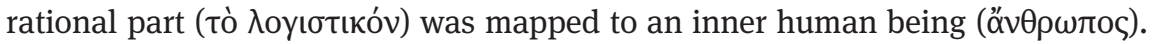
Here in Epictetus 2.9, we likewise have a comparison in which appetitive behaviour (2.9.4) is lined up with "beasts" ( $\theta \eta \rho i ́ \alpha)$ and "spirited" behaviour (2.9.5), with

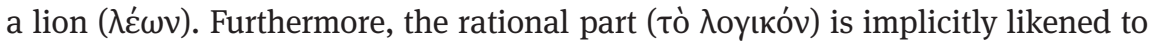
"the human", given that having destroyed "what is human in you" (ő $\theta \rho \omega \pi$ s

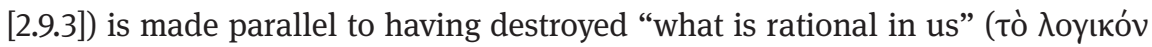
[2.9.4]). This confirms that Epictetus is drawing on Platonic as well as Stoic tradition.

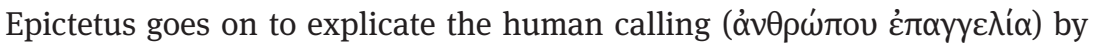
broadening the discussion to other beings and their "promised" function. In this he is a clear exponent of the kind of wider tradition that one finds in the épyov or "function argument" in Aristotle's Nicomachean Ethics. ${ }^{43}$ The functions are not only assigned to humans, animals, material objects, but even to "logical entities"44:

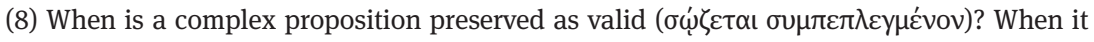

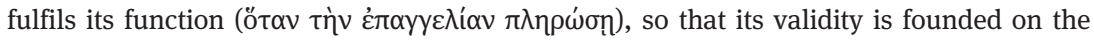

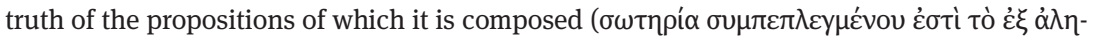

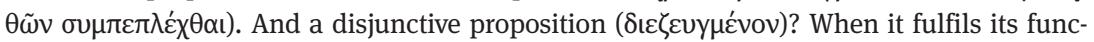

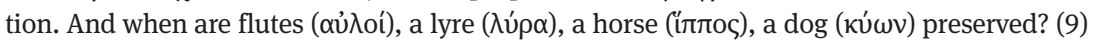
Is it surprising, then, that a human being, too, should be preserved in the same way, and

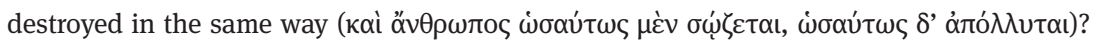
(Epictetus 2.9.8-9)

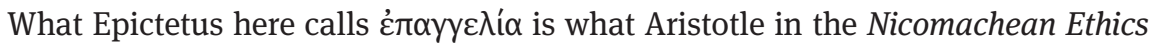
1.7.9 - 16 calls हैpyov, that is the task, function, or role of a being based on its spe-

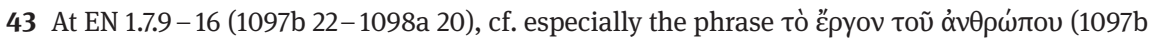
$25-26)$. The paragraph number 1.7 refers to the Loeb volume; German editions differ, assigning the number 1.6 to this passage (e. g. Dirlmeier 1960). On the function ("丷pyov) argument see Lawrence 2001; Lawrence 2006. A precursor to the argument in Plato is Resp. 352d-354a (cf. Dirlmeier 1960, 277). Cf. our discussion, in section 2.2.6.3, of Aspasius, who clearly expresses that the

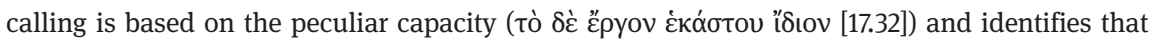

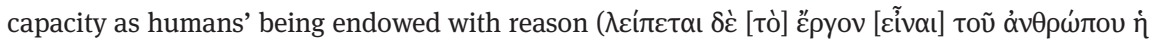

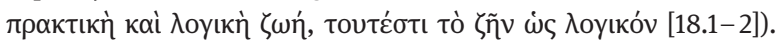

44 On logical entities in Stoicism see Forschner 2018, 31-92, in particular 51-55 (on the ov $\mu$ -

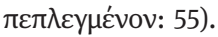


cific capacity. Crucially, as we shall see, Epictetus himself uses ع́pyov in this sense in the passage we have claimed to be the best parallel for Rom 12.1, in Epictetus 1.16.20-21. That Epictetus here draws on such a tradition is also clear from the fact that his examples are similar. ${ }^{45}$ Epictetus' language of an $\alpha \dot{v} \theta \omega \dot{\pi} \pi 0 v$

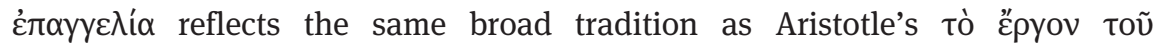

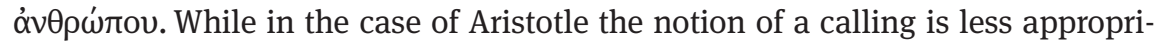
ate, because there the function is not obviously related to a divine intentionality, in the case of Epictetus it clearly is (as we will see in Epictetus 1.6 and 1.16). We further note that the language of preserving ( $\sigma \omega \dot{\omega} \zeta \varepsilon \tau \alpha \mathrm{s})$ is notable in a connection with what it means to be genuinely human. ${ }^{46}$

Epictetus then goes on to discuss, in terms that resonate closely with the model of the Nicomachean ethics, that human beings strengthen their function precisely by the right actions that correspond to these functions (2.9.19). The examples used are a carpenter and a grammarian; both are also favourite examples of Aristotle. ${ }^{47}$ And just as the carpenter stays a carpenter by performing his job, ${ }^{48}$ so also with ethical attitudes or comportment, which are thus explications (in rather conventional terms) of what properly is the human calling, as projected on to the ethical plane:

(11) A modest character is preserved likewise by modest actions (

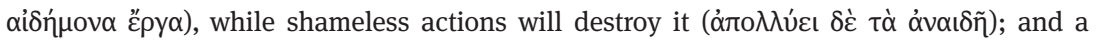
faithful character is preserved by acts of fidelity, while acts of a contrary nature will destroy

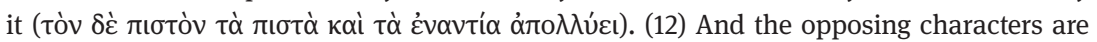

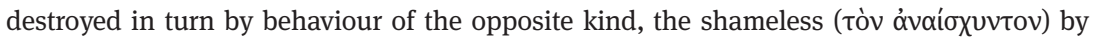

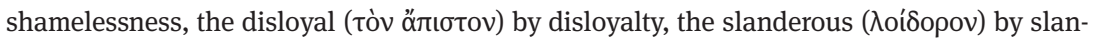
ders, the irascible (ópyílov) by anger, and the miser ( tween what he takes in and what he gives out. (2.9.11-12)

Epictetus makes here a link between actions (हैpy $\alpha)$ and the genuine humanness which they preserve ( $\sigma \omega \hat{\zeta} \zeta \varepsilon \mathrm{c})$, between the character of the human beings and

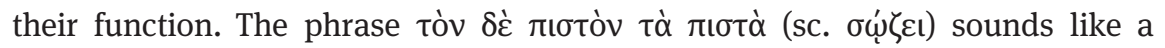
very interesting parallel to Paul's letter to the Romans, when read, as we

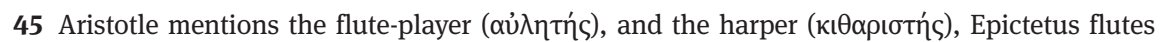

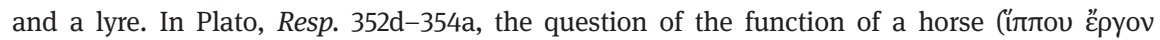

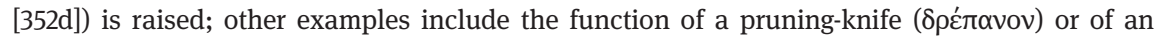
eye (so also in Aristotle, EN 1097b 31).

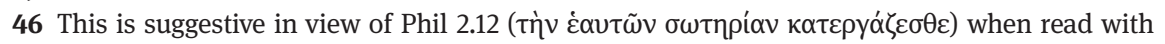
reference to the calling of those in Christ. See also our argument in chapter 5.

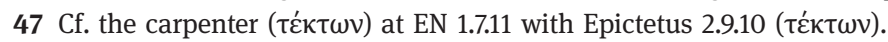

48 Epictetus does not seem to make use here of the distinction Aristotle makes between playing the lyre and playing the lyre well (EN. 1.7.14). 
argue, as being about genuine humanness. Epictetus lists negative characters

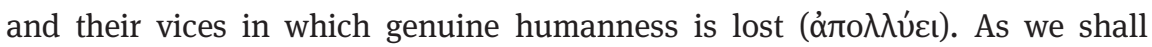
argue, the function of the vice list in Rom 1.29-31 is very similar.

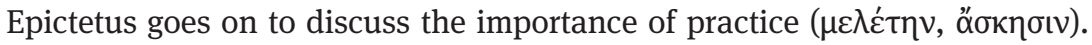
He illustrates the difference between living and practicing the Stoic doctrine on the goods from merely paying lip service ${ }^{49}$ with a good bottle of wine, which can be kept unopened in the cellar to impress the guests every so often, but which truly benefits only the one who actually drinks it. As a further illustration, interestingly, he makes a point about the difference between merely posing as a Jew and actually, through baptism, having become committed to this way of life. ${ }^{50}$ Towards the end of the Discourse, Epictetus distinguishes between the human calling and that of a philosopher, which seems like a specialisation at a higher level:

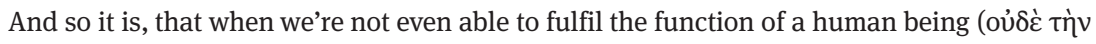

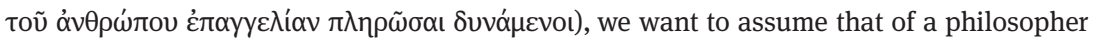

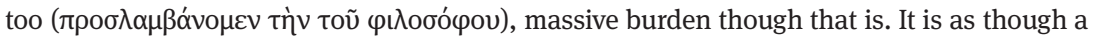
man who is incapable of lifting ten pounds wanted to lift up the rock of Ajax! (Epictetus 2.9.22)

Epictetus here criticises the pretensions of those who aspire to be philosophers, while they have not even reached what would be appropriate for them as human beings. In another Discourse, Epictetus lists being a philosopher among the "specialisations" of the general standard, genuine humanness:

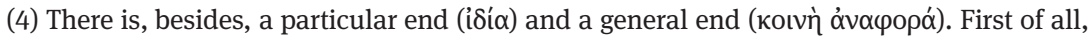

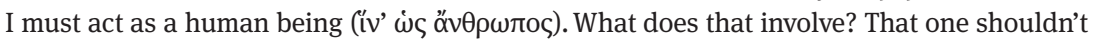
act like a sheep, even if one is gentle in one's behaviour, and one shouldn't act injuriously like a wild beast. (5) The particular end relates to each person's specific occupation and

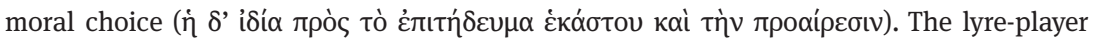

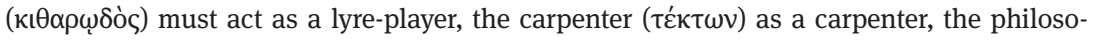

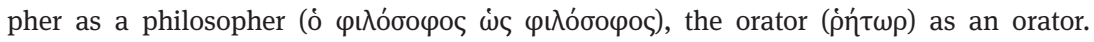
(Epictetus 3.23.4-5)

This passage, which shares much with what we have just seen in Epictetus 2.9, shows that there are different ways of being genuinely human, at the concrete

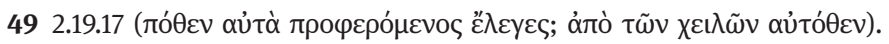

50 Epictetus 2.9.13-21. This seems like an interesting parallel to Rom 2.25-29, especially 2.9.21

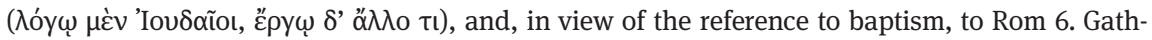
ercole 2017, 282 n. 13 compares the passage to Gal 2.11-14. See Huttunen 2017, 314-319 for a detailed argument that the reference in this passage is to Christians. 
level where there are occupations. ${ }^{51}$ In many ways, Epictetus 2.10 goes over similar ground as Epictetus 2.9, and, like the passage just quoted, distinguishes further roles. ${ }^{52}$ In the next section, we will look at the importance of divine providence for the human vocation in Epictetus. We will quote Epictetus 2.10.1-4 as a fitting conclusion to this section and as a transition to the next one. For it combines the emphasis on genuine humanness we have seen in Epictetus 2.9 with the articulations of the human vocation we will find in Epictetus 1.6 and 1.16. Furthermore, it mentions the divine ordering of the world as something that can be discerned by means of the specific human capacity. Finally, it shows how Epictetus can use various metaphors to speak about the human role in the cosmos and how self-knowledge with regards to one's identity is a basis for the exercise of one's vocation:

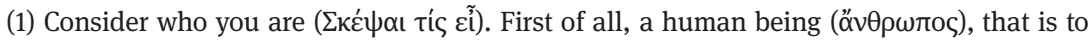

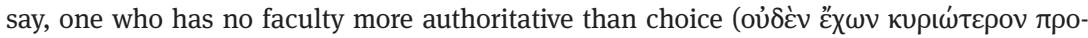
$\left.\alpha \iota \varepsilon^{\prime} \sigma \varepsilon \omega \varsigma\right)$, but subordinates everything else to that, keeping choice itself free from enslavement and subjection. (2) Consider, then, what you're distinguished from through the posses-

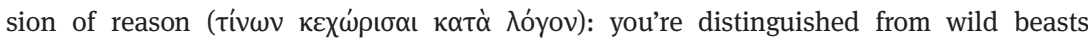

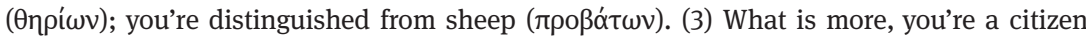

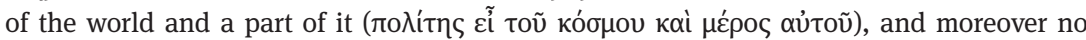

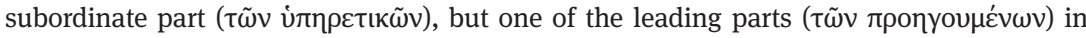

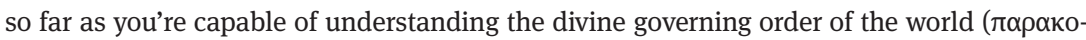

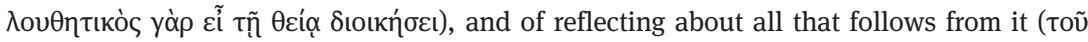

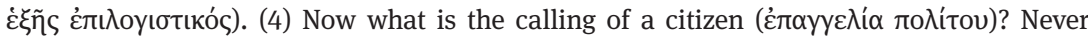
to approach anything with a view to personal advantage, never to deliberate about anything as though detached from the whole, but to act as one's hand or foot would act if

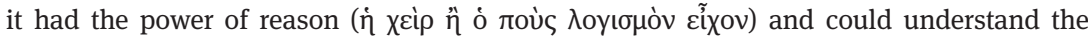

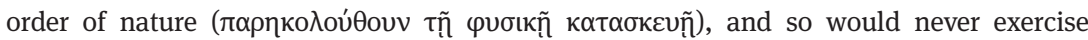

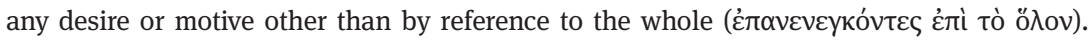
(Epictetus 2.10.1-4) ${ }^{53}$

51 For a similar distinction, cf. the four personae doctrine of Panaetius related at Cicero, Off. 1.107-116.

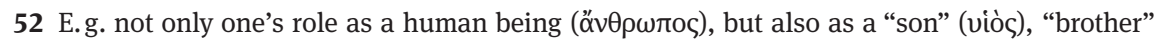

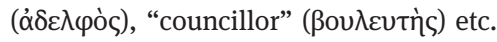

53 Note that Epictetus 2.10.4 is also an interesting parallel to Rom 12.3-8 (see section 7.3.1). Further, it uses $\lambda$ oyı $\mu_{\text {ó }}$ for the distinct capacity of human beings. We have already noted its use of

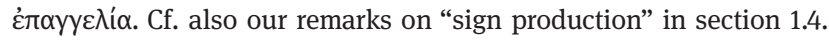




\subsection{Divine providence and the human vocation in Epictetus 1.12 and 4.7}

In this section we show how Epictetus thinks about divine providence and why the human role in the cosmos involves recognising it, based on a reading of Epictetus 1.12 and 4.7.

Epictetus 1.12.1- 6 makes a clear connection between the belief in providence and the human vocation. Epictetus first lays out the basic questions of Stoic theology, starting with the existence of gods ${ }^{54}$ and moving on to special and even individual providence: ${ }^{55}$

(1) With regard to the gods $(\theta \varepsilon \tilde{\omega} v)$, there are some who say that the divine doesn't even exist

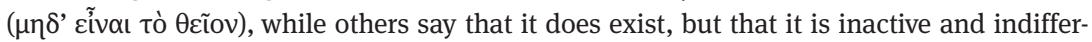

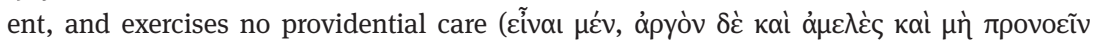
$\mu \eta \delta \varepsilon v o ́$ ); (2) while a third set of people maintain that it both exists and exercises providential care, but only with regard to important matters relating to the heavens, and in no way

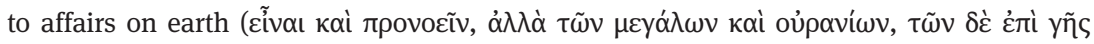

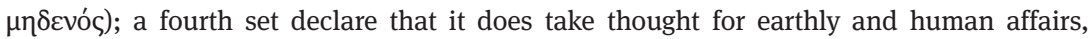
but only in a general fashion, without showing concern for each particular individual

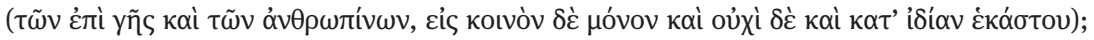
(3) while a fifth set, to which both Odysseus and Socrates belonged, say, "Not a movement of mine escapes you". ${ }^{56}$ (Epictetus 1.12.1-3)

Epictetus is giving an overview of possible positions, not listing the opinions of the philosophical schools. Nevertheless, the ideas align with the schools as follows: ${ }^{57}$ The first group are atheists, which were rare in antiquity. The second group in view are the Epicureans who are the main foil when it comes to discourse on providence. ${ }^{58}$ The third group holds a view like Aristotle, where the first intellect does not think about other beings, at least not directly. There is design in the world, arrangement for the preservation of human beings as species,

54 Like Sedley 2007, xvii n. 4, we will, in our discussion of pagan philosophers, vary between the term "gods" or "God", without implication of monotheism. Despite the word's history and usage, no negative valuation is implied in our use of "pagan".

55 Cf. Cicero ND 2.3 which contains a division of Stoic theology into four parts: existence (esse deos), nature (quales sint), administration of the world (mundum ab his [sc. deis] administrari), providence (consulere eos [sc. deos] rebus humanis), though providence for individuals is not mentioned there.

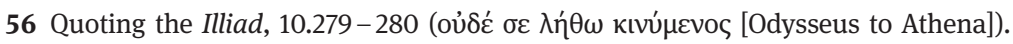

57 Cf. Gill's note in Hard 2014, 311.

58 Though the sceptic arguments put forth by the (sceptic) Academic Carneades were influential, the target of this remark is Epicureanism (cf. Long 2002, 186). Cf. Cicero's De natura deorum in which book 3 contains a critique of the Stoic position put in the mouth of Balbus. 
but not for individuals. The last two positions are Stoic. ${ }^{59}$ For Epictetus, human beings are objects of divine solicitude even as individuals. At any rate, finding

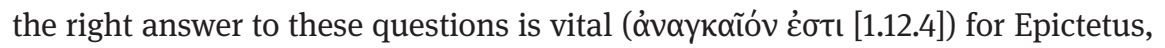
who urges his readers to examine the soundness of these propositions ( $\dot{\varepsilon} \pi$ -

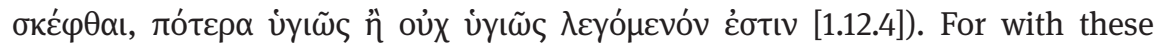
views stands and falls the possibility of exercising a meaningful human function, for which Epictetus here uses the language of "following the gods": ${ }^{60}$

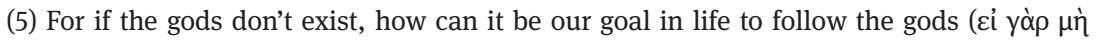

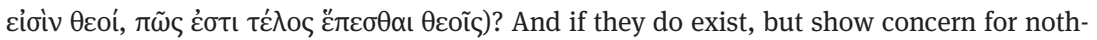

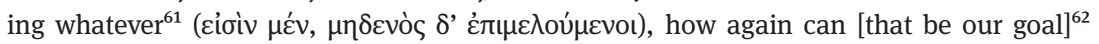

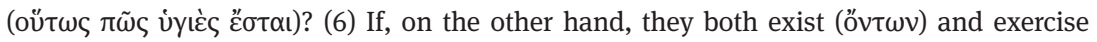

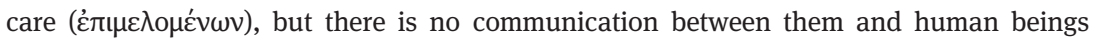

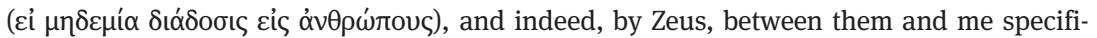

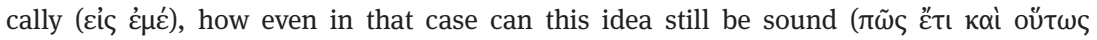

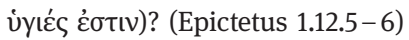

Epictetus makes the point that without a belief in divine providence, it does not make sense to speak of a human vocation. The language of "following the gods" is often taken in Greek philosophy as a formula for the goal of human life". ${ }^{63}$ The concrete behaviour which Epictetus commends in this Discourse itself is to be able to accept the things that one cannot change and in this to find freedom. ${ }^{64}$ In order to fulfil that part of one's vocation, it is necessary, Epictetus thinks, to internalise precisely the right answers to the fundamental theological questions, whether one has (theoretically) achieved sage status, or is still being educated towards the goal:

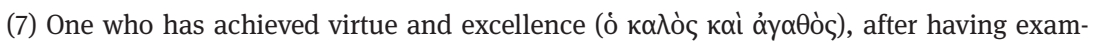

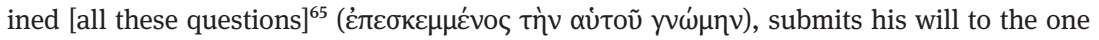

59 Cf. also the intermediate position expressed in Iamblichus' Protrepticus.

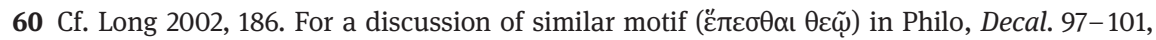
see van Kooten 2008, $190-191$.

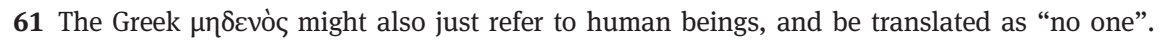
Hard's translation presupposes the general Stoic tenet that no detail escapes divine administration, even beyond the human sphere.

62 A translation closer to the Greek wording would be: how will it be a sound [proposition] (namely that the goal is to follow the gods).

63 As Gill notes in Hard 2014, 311. Cf. Epictetus 1.20.15.

64 The prime example is Socrates when he faces death, and yet is not in "prison" because he is there willingly (1.12.23).

65 A more verbal translation would be after having examined one's judgment or opinion ( $ү v \omega \dot{\mu} \mu)$ (on these matters). 


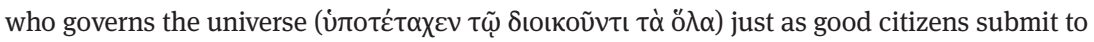

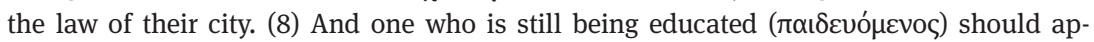

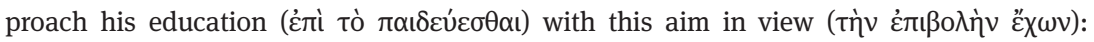

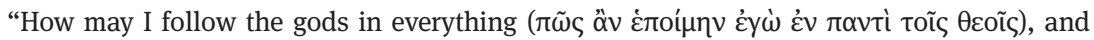

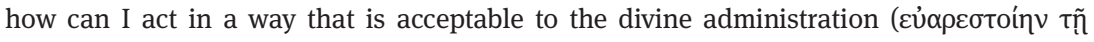

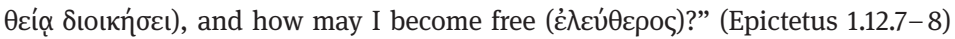

Epictetus here acknowledges a difference between those who have achieved it, and those who are still on their way towards the goal. But for both the insight into the "divine administration", into the providential arrangement of the cosmos, is the basis of their human vocation. This insight is to be pursued in every aspect of daily life. For Epictetus, the scope of one's vocation is comprehensive. It can be described as submitting to the whole and being well-pleasing

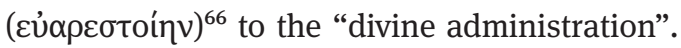

The following points summarise our discussion of Epictetus 1.12: First, Epictetus connects a theological frame of providence with the idea of a human vocation. Second, Epictetus uses different language and imagery to express the idea of a human vocation. Third, Epictetus may concretise the idea of a human vocation to certain behaviour in particular situations (in 1.12, accepting what cannot be changed). Fourth, in order to be able to live (or to learn to live) one's calling, it is essential to have insight into God's relation to the world, namely to understand that there is divine providence for human beings and that they correspondingly have a role in the cosmos.

These conclusions are underwritten by the second passage we consider for the connection between cosmic order and human purpose. In Epictetus 4.7, human beings are described as being able to see that there is providence in the way the world is "governed" and to respond appropriately (in their disposition). Having discussed the "madness" of the so-called Galileans ${ }^{67}$ who are thereby driven to react indifferently to the things (guards, swords etc.) that usually strike fear in the heart of those under some powerful person, Epictetus makes the point that it should be possible to arrive at such a fearless attitude by a rational insight:

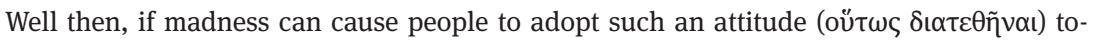
wards these things, and habit too, as in the case of the Galileans (oi $\Gamma \alpha \lambda$ ı $\lambda$ ĩoı), can’t reason

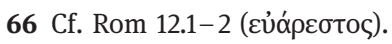

67 Hengel 1961, 60-61 argued that in Epictetus 4.7.6 the designation oi $\Gamma \alpha \lambda \iota \lambda \alpha$ ĩo is used for Zealots; Stern 1974-1984, 1.541 expresses doubt about this view. More recent scholarship (Vollenweider 2013, 125; Gill in Hard 2014, 341; Gathercole 2017, 280-282; Huttunen 2017, 310 314) sees here a reference to Christians, which in our view is the most likely option. 


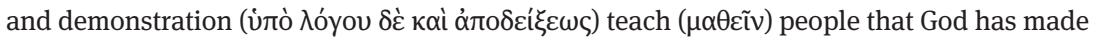

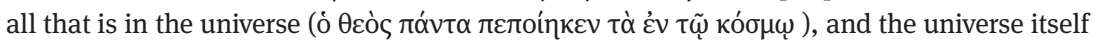

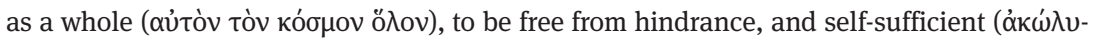

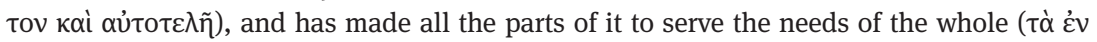

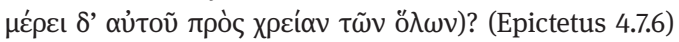

For Epictetus, it is possible by reason to learn that God is the creator of the world, which is ordered and a whole, and as such has a purpose (to be free and self-sufficient). Furthermore, all the parts within that larger cosmos are

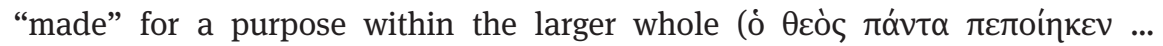
$\pi \rho o ̀ \varsigma ~ \chi \rho \varepsilon i ́ \alpha v ~ \tau \tilde{\omega} \nu$ ö $\lambda \omega v) .{ }^{68}$ This includes all the animals in the cosmos: nonhuman animals are made for humans, but human beings are unique in not only having a purpose within and for the larger whole, but in that they are both able and "called" to understand the "divine governing order":

Now, all other animals have been excluded from being able to understand the divine gov-

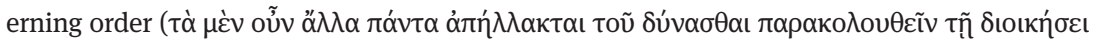

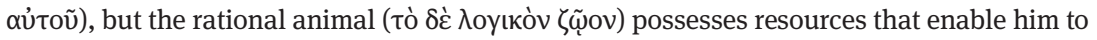

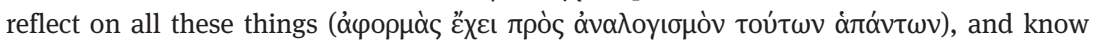
that he is a part of them, and what kind of part, and that it is well for the parts to yield

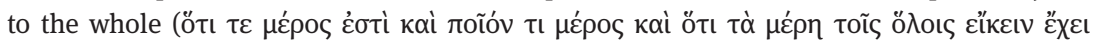
$\kappa \alpha \lambda \tilde{\omega} \varsigma)$. (Epictetus 4.7.7)

For Epictetus, all parts of the universe have a role to play in virtue of the kind of

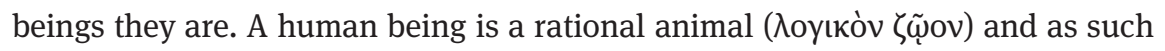

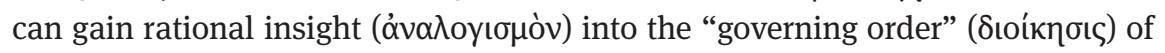
the larger whole of which it is a part. For Epictetus, human beings as a rational animals have the capacity to develop the insight into the order of the whole and the ability to act on the basis of this insight. But it is still something that needs to be realised, a vocation to which one has to aspire. Being human implies having

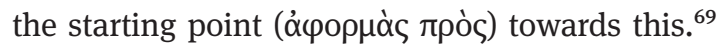

To conclude: Epictetus 1.12 and 4.7 show how the recognition of divine prov-

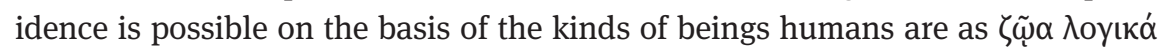

68 This is of course bed-rock Stoicism, as one can see, for instance, in Marcus Aurelius 8.19:

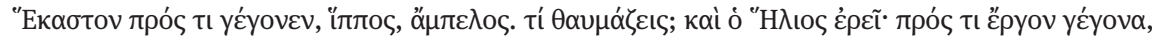

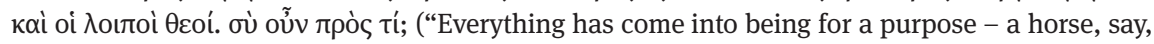
a vine. Does this surprise you? Even the sun will say, 'I came into being for a purpose': likewise the other gods. For what purpose, then, were you created?” [transl. M. Hammond]).

69 For Paul, as we will see in the next chapter, the transformation brought about in the Christ event and appropriated in baptism amounts to a change of conditions in which the human calling can finally be realised. 
and that it is necessary to recognise it in order to be able to fulfil the human calling. Divine providence for human beings is a key aspect of Epictetus' theology and it is central to his account of the human calling. At this point, we can embark on our reading of Epictetus 1.16, where divine providence is a crucial aspect of how Epictetus describes the human vocation.

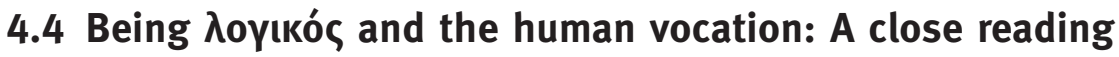 of Epictetus 1.16}

In this section we provide a full exegesis of Epictetus' Discourse $1.16 .^{70}$ We show

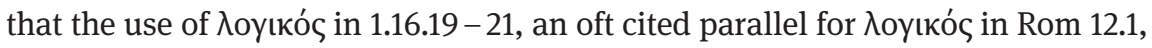
should be understood as the distinctly human capacity on which a human vocation is based. Such an exegetical approach is necessary for two reasons. First, since Epictetus 1.16.19-21 is the climax of the entire Discourse, and thus its meaning is charged by the themes developed in the preceding text (1.16.1-18), it is necessary to attend to these themes in the order of the text. Second, we are only able to show how Epictetus' discussion is rooted in the larger tradition on what it means to be human and the human role in the cosmos, if we can point out for individual themes how they belong to this wider ancient discourse. In this way we can show that and how Epictetus is also a spokesman of wider traditions on which Paul could draw and, as we shall argue, does draw as he wrestles with the implications of the Christ event and what it implies for fulfilling the human vocation within the inaugurated new creation.

\subsubsection{Epictetus 1.16.1-18}

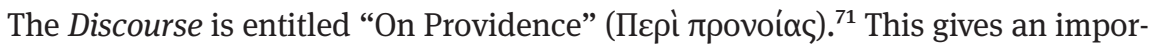
tant clue to several of the topics which appear in the discourse. We have seen in the last section that the recognition of divine providence is particularly important for Stoic accounts of the human vocation. ${ }^{72}$ Clearly, if no purpose and design

70 Readers of Epictetus may be grateful that there exists a commentary on the first book of the Discourses (Dobbin 1998). We have benefitted from its learnedness and, where this is needed for our argument, have expanded some of its densely stated points. We disagree with the view Dobbin seems to favour in his reading of 1.16.20.

71 The titles were probably given by Arrian (cf. Dobbin 1998, 65).

$72 \mathrm{Cf}$. also Epictetus 2.14.11, where existence and providence are the first things to be learned for philosophers, i.e. Stoics (cf. Long 2002, 186). 
is to be found in the institution of the larger cosmos, then there is also no place for a human purpose within such a larger cosmos, based on that order.

Epictetus starts with a common observation in ancient anthropological discourse, ${ }^{73}$ namely that animals come to the world readily equipped with bodies that keep them warm, armed and that allow them to nourish themselves from early age, while humans need all these things (1.16.1). But these features of design among non-human animals, ${ }^{74}$ Epictetus argues in common with Stoic tradition, ${ }^{75}$ are to be evaluated as signs of providence for humans, as they exist and were created for the sake of humans and for their service ( $\tau \dot{\alpha}$ yò $\rho$ oủk $\alpha u ̛ \tau \tilde{\omega} v$

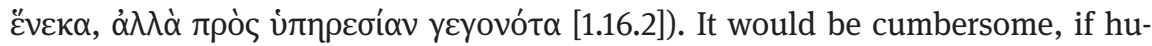
mans would have to provide clothing and food for their sheep and donkeys (1.16.3). Epictetus then illustrates the way in which nature has equipped the animals for our service with an image from the domain of military service:

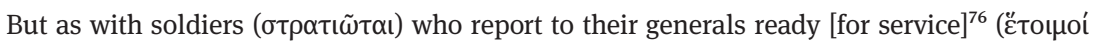

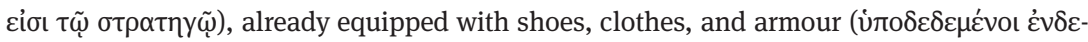

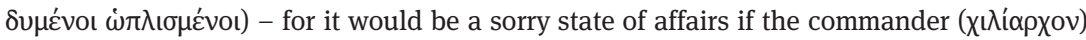
had to go around seeing to the clothes and shoes of all the troops of his regiment - so na-

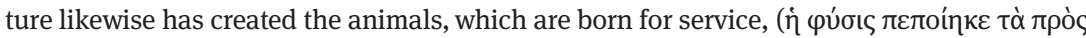

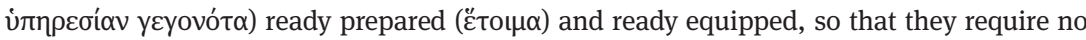

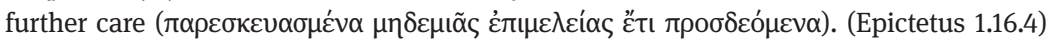

Even the livestock has come into being for a certain service ( $\pi \rho$ ò In the bodily features and equipment that can be seen in animals humans could once more learn, Epictetus tells us, what they could have learned in many other places as well: things have been providentially and divinely arranged for our benefit. The ease of husbandry given that no further care is required ( $\mu \eta \delta \varepsilon \mu$ io $\varsigma$

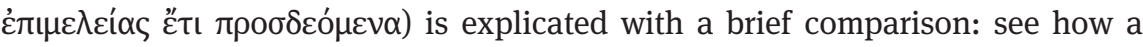
small boy with a stick can keep control of an entire flock of sheep (1.16.5).

This is the objective situation as it presents itself to the Stoic vision. It would be toilsome if we had to care for the sheep and donkeys and so we could be

73 Cf. section 3.1.4.

74 In view are especially animals used for husbandry. On ancient teleological arguments see the rich material collected in Pease 1941. An excellent description of ancient arguments from design is Sedley 2007.

75 Cf. Cicero, ND 2.64, 2.160; for further texts, see SVF 2.1152-1167.

76 Hard's translation is paraphrastic but gets the sense right. We sometimes indicate with square brackets the words supplied in the translation which do not correspond directly to Greek words but seek to clarify contextual or co-textual information.

77 Cf. Epictetus 2.10.3 quoted above. 
grateful for the way in which things have been arranged for our benefit. There is a certain order of things, we can discern it, and we should be grateful for how it is beneficial to us humans.

The world may exhibit features of design that benefit all species alike, such as the regularity of the seasons or the general habitability of the earth. But the examples Epictetus chooses deliberately focus on humans and what is beneficial for them. ${ }^{78}$ While the claim that the other animals are made for the use of humans invites the label of "anthropocentrism" 79 , the agricultural usefulness of animals is here a basis from which Epictetus argues that the world was made with the benefit of humans in mind. The animals that serve for human sustenance have a purpose, for which they have been made even though they may never be aware of it. But human beings have the capacity to recognise, with the example to which Epictetus draws our attention, that there has been an arrangement on the part of the whole and that a specific part of the whole, the animals, have a purpose $^{80}$ and that this purpose relates to humans, enabling them in turn to live and do what they are called to do within the cosmos. While animals, for the Stoics, behave directly as nature has seen fit to instruct them, ${ }^{81}$ and for which purpose she has accordingly equipped them, the human capacity and purpose includes a qualitatively novel element: the possibility of variety in behaviour, of (seemingly ${ }^{82}$ ) unpredictable behaviour, of choice. And with choice comes the possibility of error and wrongdoing. They can choose not to exercise their capacities or exercise them in the wrong ways. Based on their recognising and understanding a certain feature about the world, ${ }^{83}$ they should be moved to an appro-

78 Cf. Dobbin 1998, who briefly comments on Epictetus' choice of examples in 1.16 that they "have the advantage of touching mankind more nearly" in that they argue not just "from design", but "from god's solicitude for mankind specifically" (159-160). Dobbin draws attention to several texts we have already discussed in section 4.3 (see also Long 2002, 186).

79 Cf. Sorabji 1993 for the ancient debates and modern viewpoints.

80 Here humans look at a part of the world that does not include them and find a certain purpose. When they look towards themselves, they are able to gauge an altogether higher purpose. This self-knowledge or self-awareness, is one of the fundamental points for Epictetus, in keeping

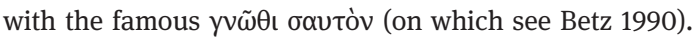

81 The concept of "instinct" has Stoic precursors, cf. Dierauer 1977, 217.

82 We cannot enter here the discussion of Stoic determinism (cf. the excellent discussion by Bobzien 1998). The basic idea seems to be that "Zeus" already calculates in his world plan that the irrationally driven human fool will deviate from what proper reason would dictate, such that the fool acts according to the divine plan precisely by deviating from proper reason, being at the same time unfree and yet fulfilling the higher purpose, while the wise man follows his own reasonable choice freely, and Zeus can let him do his own thing, because, being wise, he does the one thing that proper reason would have mandated anyway.

83 Here the utility of the "ready-made" livestock. 
priate response: the proper human response to the recognition of such a feature would be gratitude specifically for this feature. And they should then exercise their gifts to express that understanding in an act of gratitude, for which speech or even song is a possible realisation. ${ }^{84}$ But most often humans do not react in this manner:

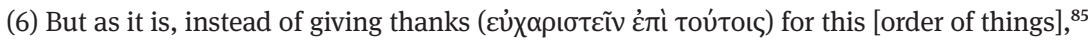

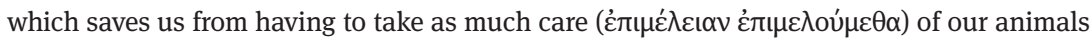

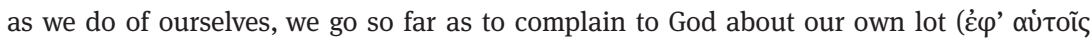

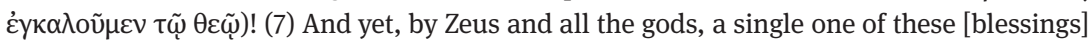

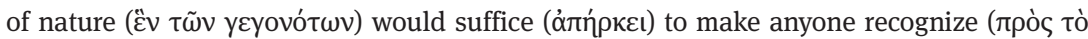

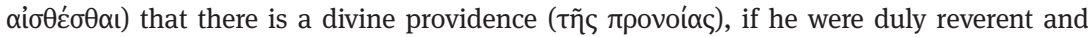

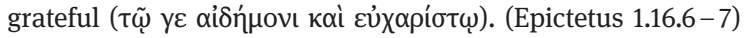

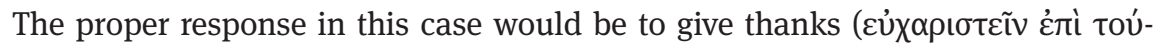

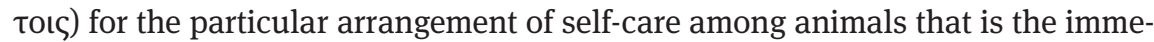
diate topic. ${ }^{86}$ And though Epictetus has, so he might say, given a clear example as evidence of the benevolent arrangement for humans, they do not merely fail to be duly grateful, but even blame God, and precisely on account of how things

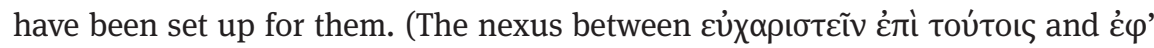

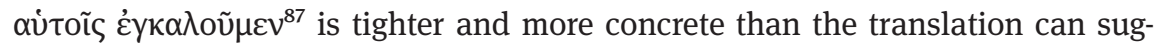
gest.) And since it is clear that the given example was just one among many, and any other thing might have told the same story, Epictetus then recasts the point in more general language: any one thing that has come to be (๕̂े $\tau \tilde{\omega} v$ yعyovó $\tau \omega v)^{88}$ should furnish sufficient proof for the perception of divine providence, i.e. of an arrangement beneficial to humans, taking care of them. Human beings, Epictetus seems to suggest, could look at any particular part of the universe, grasp the way in which it has been planned and designed, the rationality which has been operative in it, and then articulate this appropriately. And not just in an intelligent and accurate manner, as "neutral" statement about

84 On gratitude in Epictetus see Klauck 1989.

85 We have indicated paraphrastic elements in Hard's translation in square brackets.

86 The translation of Robin Hard expands some of the brief and elliptic phrases of Epictetus in a helpful way, generally. In this case, the change between the particular feature discussed and the more general and abstract proposition which would include the particular case is slightly blurred by these explanatory additions. The immediate generalisation follows in the next paragraph of Epictetus.

$\mathbf{8 7}$ The word could be as strong as charging and blaming in a court setting: "prosecute", "take proceedings against" (LSJ).

88 Here again the addition "blessings" in Hard's translation is useful and correct, but the Greek seems to be stronger and wider in scope: any created thing could be consciously focused on. 
it, but in gratitude, that is, in an ethically relevant manner, given the close nexus between being and meaning, that which is true and that which is good in much

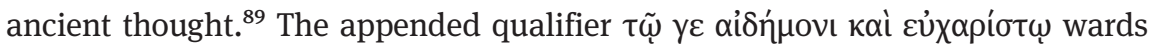
off the reply that many may fail to see it or fail to be grateful, explaining that this is because they are often not behaving as they should given who they are as human beings.

Further expanding upon the point that almost everything could point to providence ${ }^{90}$, Epictetus branches out to further yet related examples of providence, explicitly mentioning that it is in small matters that one can recognise design:

And I'm not thinking for the moment of anything grand ( $\tau \dot{\alpha} \mu \varepsilon \gamma \alpha \dot{\alpha} \lambda)$, but the mere fact that milk is produced from grass, and cheese from milk, and wool (हैpı $\alpha$ ) from an animal's hide;

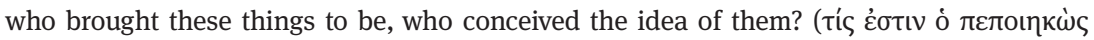

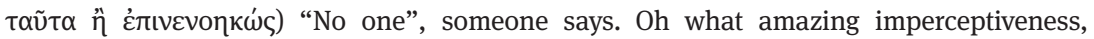

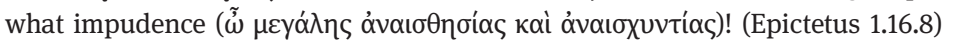

It is not that the great things ( $(\dot{\alpha} \mu \varepsilon y \alpha \dot{\alpha} \lambda \alpha)^{91}$ could not be praised, but they are not what is here illustrated. Epictetus focuses on the marvels of the food chain, by which ingeniously things are transformed into each other, in a way apt, ultimately, for human consumption, and crafted precisely to fit the bodily needs of human beings, which are implicitly mentioned earlier in the discourse ("our own needs" [1.16.3]). It is in this way that the whole is shown to be arranged such that the part is cared for, enabled for its own proper task. By speaking of wool ( $\varepsilon^{\prime} \rho(\alpha)$, and hence clothing, Epictetus revisits the theme of the "poor" human bodily equipment we have seen several times already as a fixed topic of the wider discourse on what it means to be human. Such thematic overlap strengthens our confidence that 1.16 indeed firmly belongs to that discourse. ${ }^{92}$

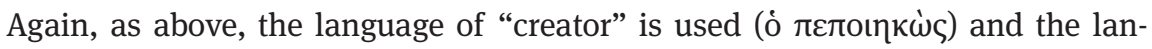

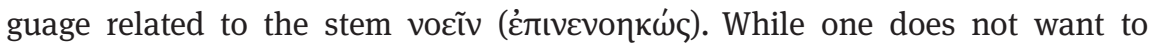

89 Cf. what we have noted already about how the so called normative fallacy put forward by Hume, Kant and others in their wake, while true for many particular cases, fails as a general rule precisely because it begs the relevant metaphysical question (petitio principii): that things are neutral before humans project significance is precisely the modern view which many ancients did not share.

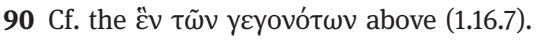

91 Dobbin $(1998,159)$ takes Epictetus to have in mind here "cosmic phenomena, such as the interchange of the elements fire, air, earth, and water". Epictetus' example of cheesemaking involved a humbler sort of transformation.

92 That humans are bodily weak (relative to other animals) may also relate to the discussion, below, of the reference to Epictetus' lameness (1.16.20). 
enter the business of philological stamp-collecting ${ }^{93}$, the voũ lexeme family is significant here, especially in view of the parallels in Romans. ${ }^{94}$ Something like an Epicurean "diatribal" interlocutor answers the rhetorical question of who made this or who came up with this in the negative ("no one").

Epictetus chooses his examples carefully. The example of the food chain here offers more than first meets the eye: ${ }^{95}$ For the livestock, willy-nilly and unawares, are involved in the first step of turning grass into milk (they need to chew to begin with) and for the second step it requires a human cheesemaker. But for both humans and sheep the world needs to exhibit the structure and features which are the conditions of possibility for both of these processes (grass to milk, and milk to cheese). In both the "earthly" agents (sheep or humans) cooperate with the overall designer "Zeus". The sheep do what they do and eat the grass and never once are aware of what they are doing reflexively. But they fulfil their role and in this way enable humans to benefit from the process. The human farmer or cheesemaker is needed in the second process, milk to cheese. At times, the farmer will be aware of what he is doing (after all, he can talk about it) and how he uses the tricks of his trade. But he might usually be so absorbed in the activity that he fails to notice, or he might be occupied about other things. Similarly, the cheesemaker, as a craftsman, employs a sort of "technical reason"96 and he uses language to communicate about it. And he might even, from time to time, turn to think about why it is that the world is such that his activity of cheese making, which he mostly takes for granted, is even possible, something the sheep never will. All this is to point out, that while on one level, obviously

93 The term has been coined by Osborn. Osborn 1993, 19 criticises Norden's argument $(1913,33)$ for the need to assume oriental origins for the idea of "knowledge of God" based on the obser-

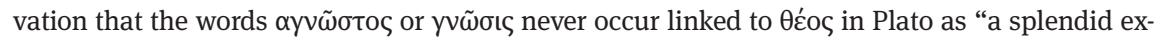
ample of philological stamp-collecting, which ignores the central principle that different words can mean the same thing and that the same words can mean different things" (19 n. 65). Edwards 2002, 7 glosses Osborn's point as the "compilation of parallel vocabularies".

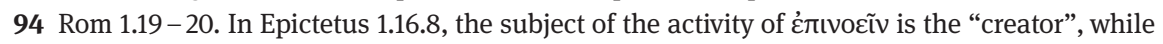

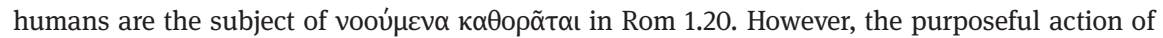
the "creator" is a condition for the possibility of humans discerning such purposes in what has been made.

95 Here we draw out the way these examples work in more depth than explored by Dobbin's commentary. The images Epictetus uses express his point clearly and accessibly for broader audiences. Hence they can more plausibly be taken to express a broadly shared stock of ideas than similar thoughts presented in more technical language.

96 Cf. the same distinction in Epictetus 1.16.18. 


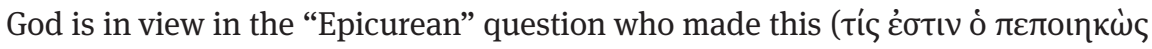
$\tau \alpha \tilde{v} \tau \alpha)$, clearly, the human or farm animal factor belongs into the equation. ${ }^{97}$

The reply to the challenge is an exclamation, which centres on two faults, the first being the lack of (proper) perception ( $\left.\alpha \dot{v} \alpha \_\theta \eta \sigma^{\prime} \alpha\right)$, recalling the perception

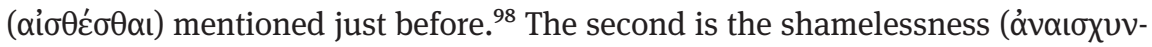
$\tau i ́ \alpha)$ involved in making the assertion "no one". ${ }^{99}$ Such language draws attention, explicitly, to the normative dimension of this discourse, which is implicitly there even without such language.

While the benefit to humans in the case of cheese is obvious, there are other little things in the universe which seem completely useless: ${ }^{100}$

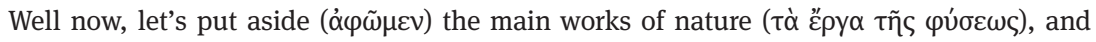

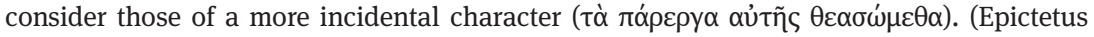
1.16.9)

As Epictetus has not discussed the main works of nature earlier in this Discourse, $\alpha \varphi \tilde{\omega} \mu \varepsilon v$ seems to signal to the "diatribal” interlocutor: the preposterousness of the claim that "no one made this" could easily be seen by looking at the main works, but we will even be able to show it by looking at the bywork. ${ }^{101}$ We fur-

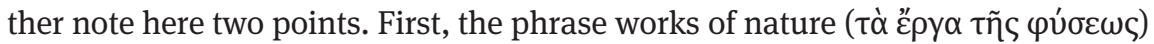
is significant. $\varphi$ vioı here could be taken in the everyday sense of nature (or slightly personified "Nature"), but for the Stoics it can stand for God, the master craftsman. ${ }^{102}$ Just as every other being so God, too, has his हैpyov, and it goes without saying that he is eminently rational. Second, while there is an unemphatic use of $\theta \varepsilon \alpha \sigma \omega \mu \varepsilon \theta \alpha$ in the sense of merely considering the next topic, the language of "seeing" should here perhaps be taken in a more weighty sense, as one of the characteristic tasks of humans. ${ }^{103}$ With this we turn to the examples, which start with the male beard: ${ }^{104}$

97 This also has to do with the way immanent world rationality is bound up with human rational agents in the Stoic world picture.

98 1.16.7.

99 We note that we are here in similar territory to the one Paul explores increasingly in Rom $1.18-32$.

100 The really challenging question for Stoics to explain is the problem of things that are bad, harmful or evil (cf. SVF 2.1168-1186). On evil within Stoicism see Long 1968.

101 For examples cf. Dobbin 1998, 160.

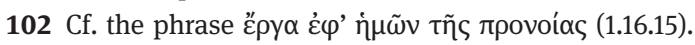

103 As we have seen in chapter 3 and 2.2.6.3. Cf. also our discussion of Epictetus 1.6 in section 4.5.

104 On the beard in antiquity cf. DNP, s.v. "Bart". 


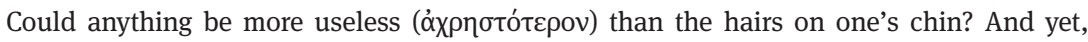

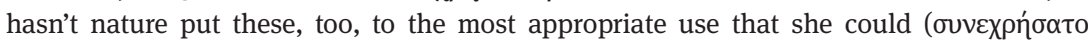

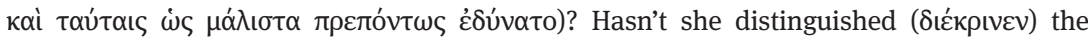

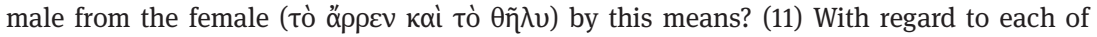

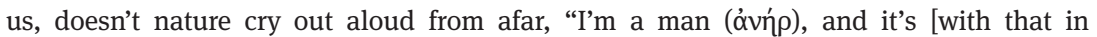

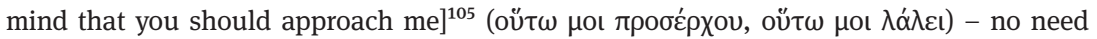

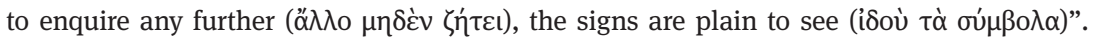
(Epictetus 1.16.10-11)

While anyone is familiar with the warming benefits of fur, facial hair seems to be useless (and thus a waste). But here, too, Epictetus finds something that has

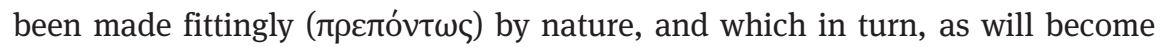
apparent shortly, is the basis for a human response. In what may be admission

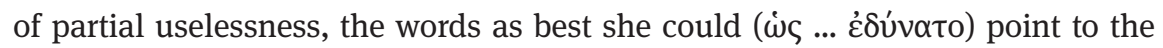
common topic of nature doing the best with limited resources: just as the demiurge had to work with limited material in the Timaeus, so, for the Stoics, did nature on the grand and the small scale. The differential hair growth will have appeared obvious and given the strong insistence upon the roles of male and female in Greco-Roman ethos, but in particular among the philosophers, ${ }^{106}$ anything that contributes to the maintenance of that difference will seem to serve a useful function. But the distinction between male and female as a topic is noticeable especially with a view to Rom 1.26-27. There is a semiotic function of the beard: at once it tells something about the nature of the thing, here the man, which in turn implies for those who see the sign both how to approach (ovit $\omega$

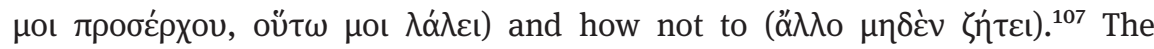
sign in question, the growing of a beard, is natural in a sense in which knowing how to sing Greek epos is not - one does not have to learn to do it. But interestingly one does have a choice: one could shave the beard or not, and further could keep it in different ways. ${ }^{108}$ Given the cultural assumptions in Greco-

105 "In this way approach me, in this way talk to me."

106 Though cf. the views of Epictetus' teacher Musonius Rufus (lecture 4), who argues that their virtue and education should be the same. For a critical discussion of Musonius' views see Nussbaum 2013.

107 We are not sure whether this remark alludes to ancient Greek sexual practice where the "loved" boy, as soon as he grows hair should be "off limits" (cf. Halperin 2012, 701: "males were customarily supposed to be sexually desirable to other males mostly in the period of life that extended from around the start of puberty to the arrival of the full beard"). If so, such an allusion to same-sex sexual relations would be an oblique parallel to Rom 1.26-27. On same-sex sexual relations cf. the literature cited in Halperin 2012 (and cf. Verstraete and Provencal 2005).

108 On the beard as note of the philosophers, see Dio Chrysostom, Or. 72.2. 
Roman tradition the beard perfectly illustrates what Epictetus wants to say: the cock cannot choose not to sport his comb, but a man could shave away his beard permanently, even though that would seem "unnatural”. The example, however, also already prepares for what is to come, because just as one might cut off one's beard, against "nature", human beings could choose not to do what would (or at least should) come naturally: to recognise the works of providence and to be moved to praise. And as he comes to the female examples, Epictetus is sure to tell us explicitly about these ethical implications:

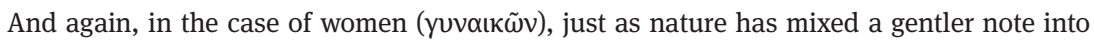

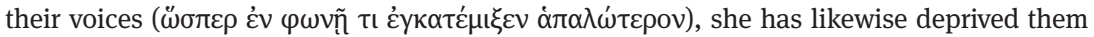

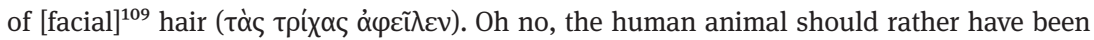

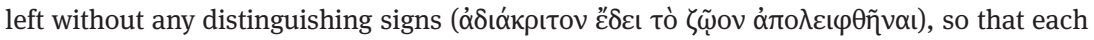

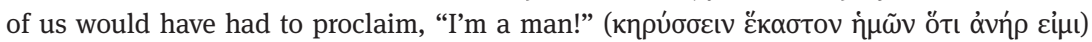

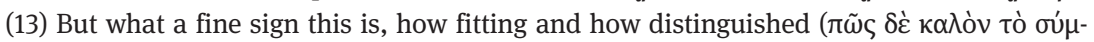

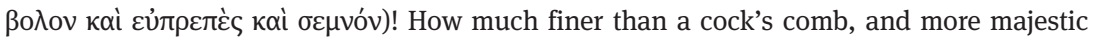
than a lion's mane! (14) It is thus only right to preserve the signs that have been conferred

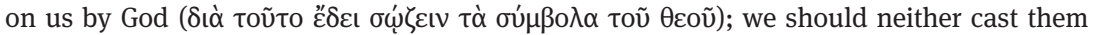
aside nor, so far as possible, confuse the sexes that he has distinguished ( $\mu$ 门̀ $\sigma u y \chi \varepsilon \tilde{v}$

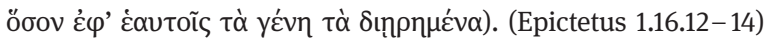

For women the absence of the beard is the sign. And the function is to signal ("herald") from afar something about the identity of the concerned person. It relieves of the communicative need to declare one's sex so humans can speak about other matters. The example thus parallels the livestock fending for itself.

Epictetus goes on to laud the aesthetic merits of the beard, adding further

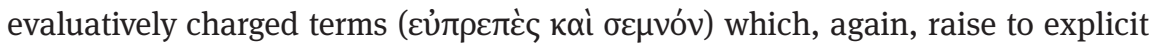
awareness the ethical context present throughout. He even takes a stand on the question of the relative beauty of the male markers of identity across species. Both the cock and the lion are perhaps notable for their virility and both show clear markers of their sexual identity. Both presumably would not dream about removing them. And with an implicit a fortiori, Epictetus seems to say,

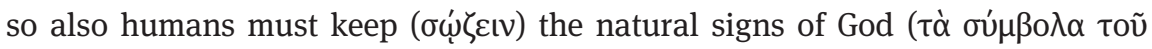
$\theta \varepsilon o v \tilde{)}$, both the particular markers of sex, and as an immediate generalisation which Epictetus does not here spell out, in general the things God has assigned. The sexual distinction must be maintained as conforming to nature and divine design.

To summarise what Epictetus does with this example of the beard: first, he discusses a feature of the world in which divine providence for human beings

109 Added from context by Hard. 
can be discerned; second, he draws out implications for human behaviour which must appropriately respond to the features as so discerned. With a view Rom 1.26-27 (see chapter 5) it is significant that Epictetus chooses an example which emphasises a certain distinction between male and female to make his point.

Epictetus has only been recounting some of the bounties of providence for humans, and there could be many more:

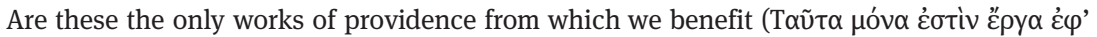

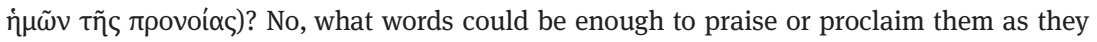

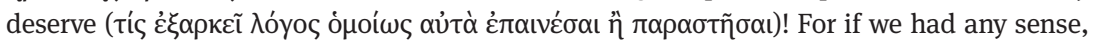
what else should we do, both in public and in private, than sing hymns and praise the

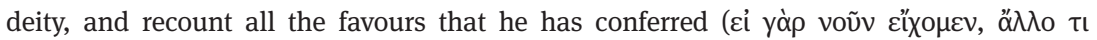

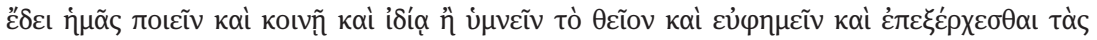

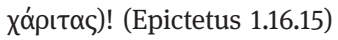

There are countless works of providence that humans could discover ( $\varepsilon^{\prime} \rho \gamma \alpha \dot{\varepsilon} \varphi$ '

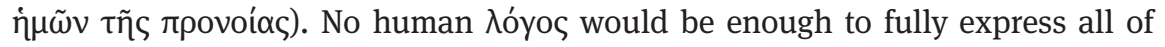

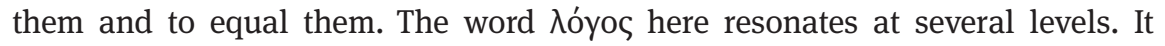
may refer both to the words used in an actual hymn and to the reason which is capable of grasping the things which deserve praise. It may also hint at the divine reason which would be required to be equal to the task. Humans are to

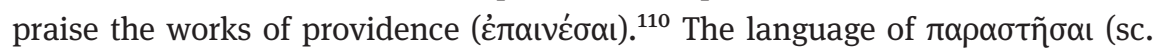

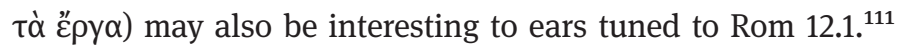

Epictetus makes a clear statement of what humans should do vis-à-vis the providentially arranged cosmos. He describes in what the human task consists, using the language of singing ${ }^{112}$ hymns and worship or praise (ن் $\mu v \varepsilon \tilde{v}$ Tò $\theta \varepsilon \tilde{o v}$

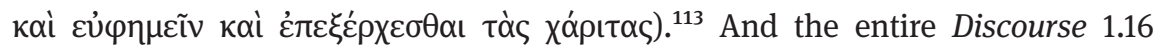
has placed these words in a context that strongly determines how we should read them.

110 This is standard terminology in rhetorical contexts, cf. Aristotle, Rhetorics for the yévoৎ દ̇ंt-

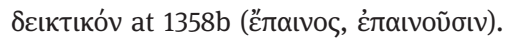

111 While $\pi \alpha \rho \alpha \sigma \tau \tilde{\eta} \sigma \alpha \iota$ may simply be used as a word like "establish" in a communicative sense, it also recalls setting up things that are presented, e.g. votive offerings or gifts brought to a temple etc. In Rom 12.1b the act of $\pi \alpha \rho \alpha \sigma \tau \tilde{n} \sigma \alpha \mathrm{s}$ involves more than words, but the act is itself communicative and as we argue precisely in terms of a sign production of how God has acted in Christ.

112 Cf. ợ $\delta \varepsilon ı v$ in 1.16.16.

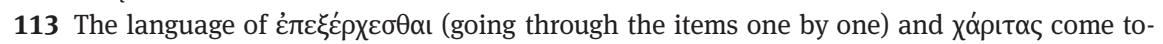
gether in an interesting blend. While the former may recall the lecture room, the latter is here used for the instances the deity has provided favours, and thus send the mind to the shrine. 


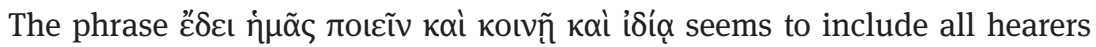
and thus Epictetus makes it clear that this is a calling that applies to all human beings, the farmer just as much as the philosopher. ${ }^{114}$ The phrase emphasises both individual and communal aspects. ${ }^{115}$ The formulation ö $\lambda \lambda$ o $\tau$...

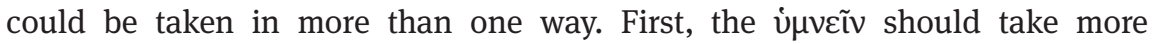
space from other activities that fill the hours of the day. Second, $\dot{v} \mu v \varepsilon \tilde{v}$ is the activity which should be performed while going about the other activities of the day. The immediately following passage supports the second interpretation:

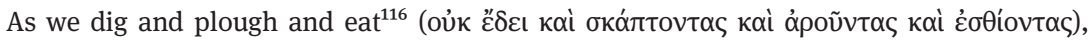

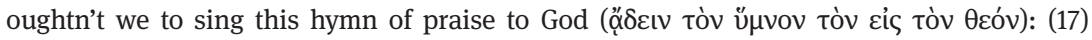
"Great is God, for having provided us with these implements with which we till the earth

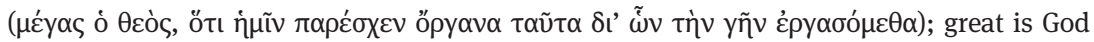

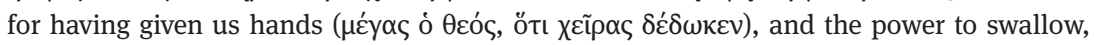

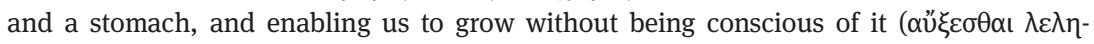

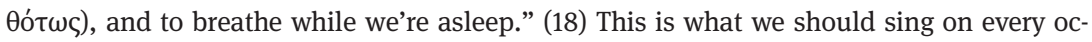

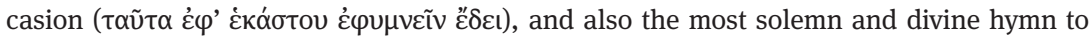
[thank God] for having given us the power to understand these things and to make method-

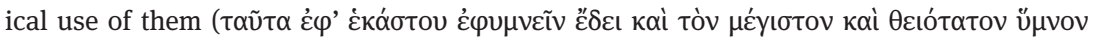

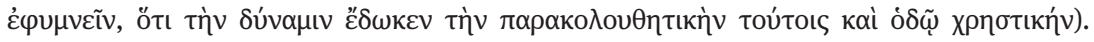
(Epictetus 1.16.16-18)
\end{abstract}

In this passage, Epictetus pictures a farmer at work or someone eating while at

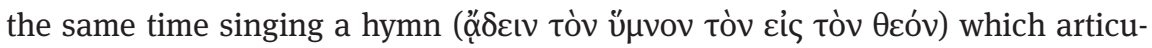
lates the features of providence that usually pass unnoticed ( $\lambda \varepsilon \lambda \eta \theta$ ó $\tau \omega \varsigma)$. Epictetus points out these features which are involved in precisely the situations in which the farmer or the person eating find themselves. In principle, they would have what it takes to understand this too and be moved to the right attitude of gratefulness. It is a reflective sort of gratitude based on an understanding of how divine providence is involved in the everyday situation. ${ }^{117}$

In this passage we see that Epictetus 1.16 uses the language of singing a hymn as a metaphor that describes what the human calling consists in. It is an excellent metaphor to describe the dimension we call sign production: the hymn articulates the understanding about God's relation to the world that can be had, expressing it in gratitude and praise towards God. Epictetus uses the image of singing a hymn to describe the appropriate human stance in every di-

114 As becomes immediately clear in 1.16.16.

115 Engberg-Pedersen 2000 has set great store by the social dimension of Stoicism.

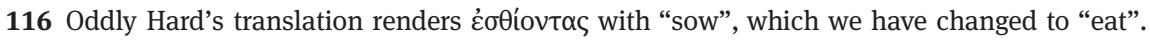

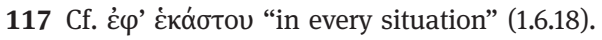


mension of life, not just when the vocal chords are actively engaged in actual singing.

The following considerations support this interpretation. First, it becomes apparent from Epictetus' use of the image, since literal singing should be hard

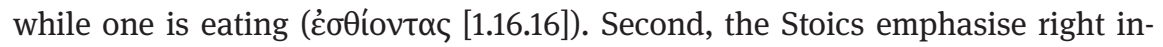
tention and the mindset involved in an action (such that the right aiming at the execution of an action is important, not the success or the results of these actions). ${ }^{118}$ Third, the comprehensive scope of the application of the image of

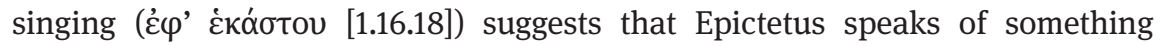
that concerns all of life, and not just specific acts of "worship".

We further note the following points on this passage. First, the mention of the hands (1.16.17) for which humans are grateful once more picks up a topic central to the ancient discourse about being human. ${ }^{119}$ Second, this capacity to un-

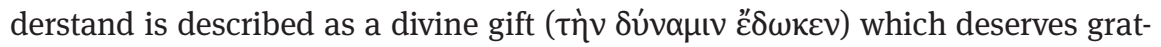
itude. It is also the gift which is needed be appropriately and reflectively grateful.

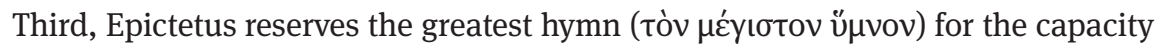
of human beings to understand things. Epictetus distinguishes the practical abil-

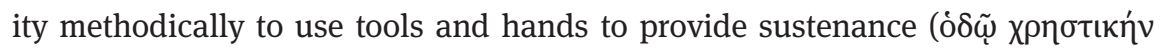
[sc. $\delta u ́ v \alpha \mu \nu]$ ) from the ability to follow the ways of God in providing for humans

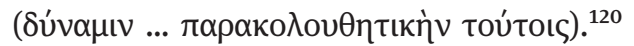

This capacity whereby humans discover and follow the course set out by nature is of signal importance for the elucidation of the human vocation by Epicte-

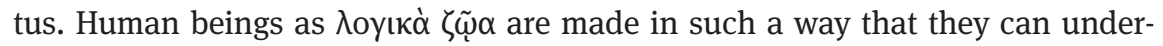
stand the world in its relation to God and respond in appropriate sign production which expresses this understanding.

\subsubsection{Epictetus 1.16.19-21}

And with this we come to the climax of the entire discourse, what we argue is the most important parallel to Paul's reason language in Rom 12.1, which we are now finally in a position to place in its own context and as part of its wider discourse. (We will quote the Greek in a segmented and numbered form for ease of reference in our analysis.)

118 On this point see Forschner 2018, 183-4. Cf. Cicero, Fin. 3.22.

119 See chapter 3.

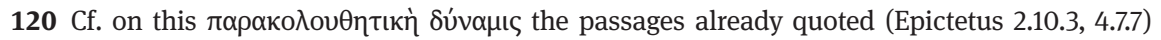
and below (Epictetus 1.6.13). See also Dobbin 1998, 161. 
(19) Well then, since most of you have become blind, ${ }^{121}$ isn't it necessary that there should be somebody to take your place, and sing the hymn of praise to God on behalf of one and all? (20) And what else can I do, lame old man that I am, than sing the praise of God? If I were a nightingale, I would perform the work of a nightingale, and if I were a swan, that of a swan. But as it is, I am a rational being, and I must sing the praise of God. (21) This is my work, and I accomplish it, and I will never abandon my post for as long as it is granted to me to remain in it; and I invite all of you to join me in this same song.

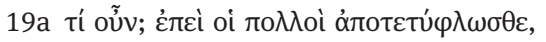

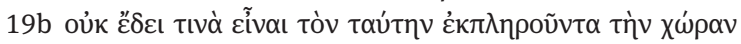

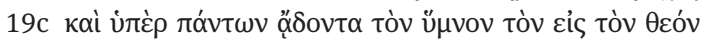

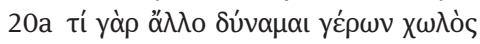

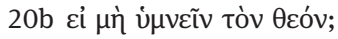

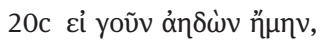

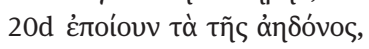

20e عi kúkvoৎ,

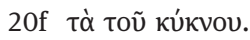

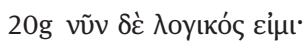

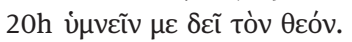

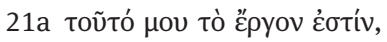

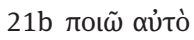

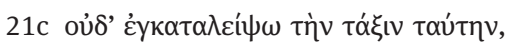

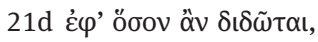

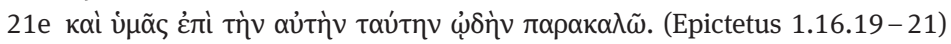

For our reading of this passage in view of it being a parallel to Romans 12.1, we argue the following points:

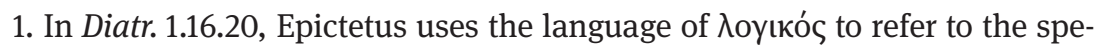
cifically human capacity, on which a human calling is based.

2. In Diatr. 1.16.19-21, Epictetus speaks of his own calling as a human being,

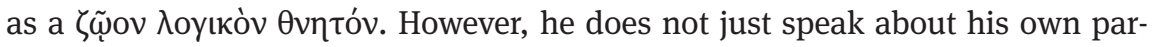
ticular vocation, but about what he sees as the vocation of every human being, i.e. the human vocation.

3. We should distinguish language used to state that there is such a vocation, from language used to describe in what actions this vocation consists. In Diatr. 1.16.19-21, Epictetus uses both. He uses the image of singing a hymn to God as a metaphor that describes the human vocation as a sign production.

4. The entire passage serves a protreptic function.

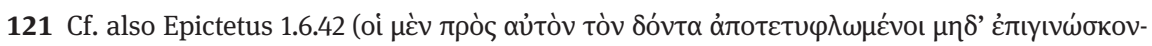

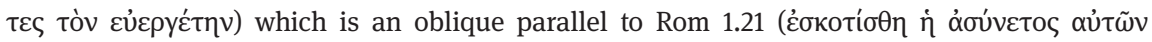
к $\alpha \delta i ́ \alpha)$. 


\subsubsection{1 入оүıко́ as the distinctive capacity}

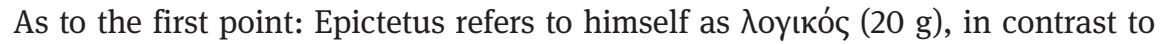

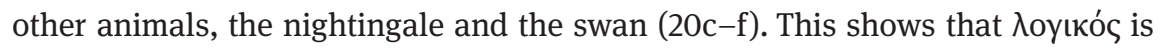
used to denote the capacity which distinguishes human beings from other animals ( $\alpha \lambda$ $\lambda \alpha^{122}$ ). It refers both to reason and speech. That both animals which Epictetus mentions in 20c-f are birds makes it possible to compare the song of the birds ${ }^{123}$ with the singing of a hymn of praise. In 21a Epictetus states that he has a task in life, a vocation, an ع̌pyov. In 21a Epictetus identifies the "singing" (ن́ $\mu$ -

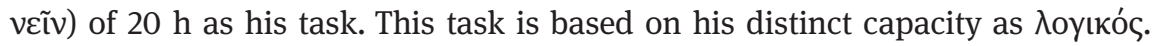
The contrast with the two other birds (20c-f) shows that what Epictetus describes as his हैpyov in 21a is in fact his human vocation. For in line with the Stoic (and more broadly shared) assumption that each being has a distinct purpose, he details for the nightingale and the swan that they also have an हैpyov, and that merely by being a bird of this or that kind, it should have to perform the

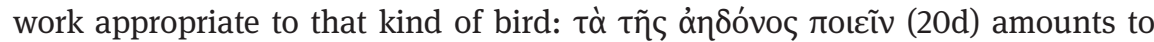

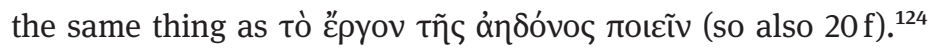

\subsubsection{A human vocation}

As to the second point: Epictetus performs an act of exhortation or invitation

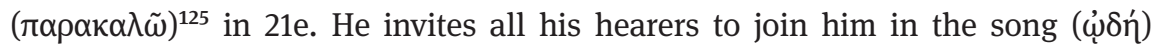
that he has identified as his vocation as a human being. By using this language, he connects that to which he invites his hearers with the key metaphor of ú $\mu v \varepsilon i v$, not only in $20 \mathrm{~b}$ and $20 \mathrm{~h}$, but also earlier in the Discourse (cf. 1.16.15-19). While in practice Epictetus' hearers belong to the well-situated, in principle all human beings are addressed, because all human beings are $\lambda о у ı к \dot{\alpha} \zeta \tilde{\omega} \alpha$, and on this the vocation is based. Thus, Epictetus speaks about his own vocation and about the human vocation. His particular calling as a philosopher is to exhort human beings to their calling as human beings. While many are blind to the providence that could be "seen" (19a), Epictetus fills out the human role in the cosmos

122 Cf. DL 7.61.

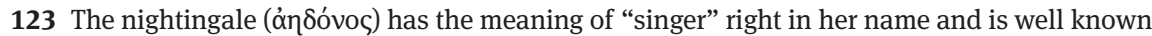
to the ancients for her singing: Pliny the Elder describes her singing (Nat. 10.81-82). There is even a fragment by Democritus where she is praised as the inventor of song. Cf. DNP, s.v. "Nachtigall”.

124 Which Hard's translation rightly adds as paraphrase ("I would perform the work of a nightingale"). Merely rendering this as "I would do what is appropriate to being a nightingale" (so Wolter, see our discussion in section 6.3.2) misses the contextual nuance.

125 Cf. Rom 12.1. 
(19b), even "singing" on behalf of others (19c); he will do this for as long as he lives $(21 \mathrm{~b}-\mathrm{d})$. But that others fail to do as he does, does not mean that it is not their calling too, merely that they fail to live up to their calling as human beings.

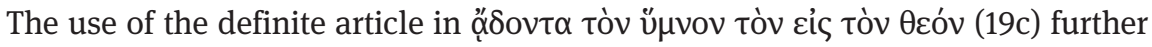
supports our reading: this seems to indicate more than that he has already mentioned this topic. Rather it recalls the key metaphor of the entire Discourse used to describe the life that fulfils the purpose of human beings in the cosmos. Thus,

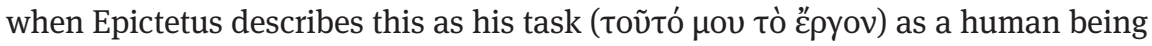

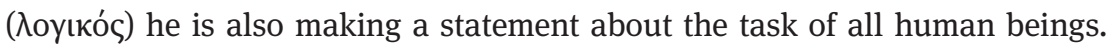

The reading we present here is in strong disagreement with an interpretation to which Dobbin's commentary seems inclined. ${ }^{126}$ Dobbin notes that the "self-reference" to his lameness (20a) "has a note of Socratic irony to it" and then refers "for the role [Epictetus] deems appropriate for his age" to a line of Hesiod:127

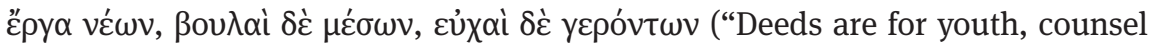
for middle years, prayers for old age”). ${ }^{128}$ This could suggest an interpretation, in

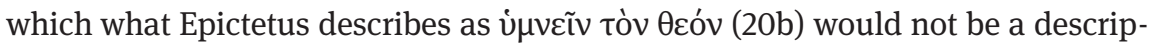
tion of a human vocation, but only something appropriate for Epictetus himself, or for someone in a similar situation, either because the movements of the body

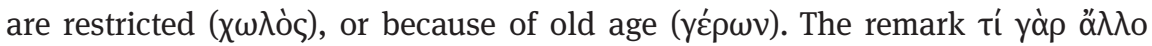

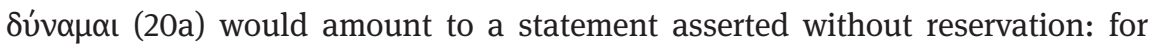
someone in my situation, only ن่ $\mu v \varepsilon \tilde{v}$ remains (where $\dot{\mu} \mu v \varepsilon \tilde{v}$ is taken to refer only to literal singing or, as in the line from Hesiod, prayers [عủxai]). This interpretation might claim the following two points as support.

First, Epictetus may hint at the end of life in $21 c^{129}$ and $21 \mathrm{~d}\left(\mathcal{\varepsilon}^{\prime} \varphi^{\prime}\right.$ ö $\sigma o v$ ôv $\delta \mathrm{t}$ $\delta \tilde{\omega} \tau \alpha \mathrm{l})$ and thus speak about his own situation as an old man.

Second, the choice of the birds as examples might hint at death as well. The deliberate choice of swan (кúkvos [20e]) might be an allusion to the end of life by recalling the idea of the dying swan's song. ${ }^{130}$ Perhaps also the fact that the nightingale sings at night might be associated with death. ${ }^{131}$

126 Dobbin's remark is brief and may not fully reflect his own position. We have adduced further possible arguments for the position, but will refute them.

127 Dobbin 1998, 161.

128 Porphyry, Abst. 2.18 (148.13 ed. Nauck) = frag. 321 ed. Merkelbach/West. The translation is as in Dobbin 1998, 161.

129 Cf. the use of similar language at Epictetus 1.9.16.

130 This idea appears, literarily, in the myth of Cycnus, the son of Sthenelus (Ovid, Met. 2.367-

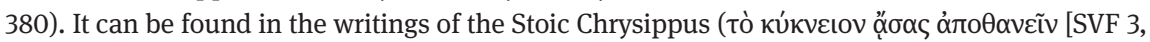
p. 199 1. 43]); Pliny the Elder expresses his doubts about the idea at Nat. 10.63. The idea of the swan sensing its approaching death and singing a final song already appears in Plato's Phaedo 
Thus, on this interpretation Epictetus would not be speaking about a human vocation. But this interpretation is wrong for the following reasons.

First, precisely because a human being is defined as a rational being, the physical condition of his body is not for Epictetus a defining factor. For a Stoic, the body belongs to external things, its condition cannot be determinative for ethical action. ${ }^{132}$

Second, there is indeed, as Dobbin notes, Socratic irony in 20a, but we suggest it works in such a way as to goad the hearers into action. It is a sly way of suggesting an (in truth) irrelevant limitation that ultimately is supposed to goad the hearers. The point is not that what he means by ن́ $\mu v \varepsilon \tilde{v}$ is for those too old to act - to the contrary, they might go about it with all the energy of youth (and to this he exhorts [21a]). This rests on understanding that $\dot{u} \mu v \varepsilon \tilde{v} v$ also functions as a metaphor (see below).

Third, the comparison with the nightingale and the swan $(20 \mathrm{c}-\mathrm{f})$ is concerned just with the different species as such and does not mention any kind of difference of age or strength. While the concept of the dying swan's song is part of the cultural encyclopedia, there are no indications in the text that this concept should be activated here. ${ }^{133}$ The far more plausible reading is that birds are used to illustrate the place of humans in the scala naturae ${ }^{134}$ and that their singing fits nicely with Epictetus' use of the image of humans singing hymns, in which they can articulate as praise their insight into divine providence.

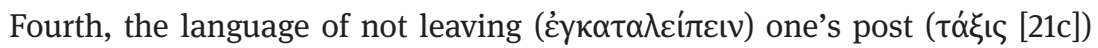
emphasises the task that one has as long as one lives (21d), irrespective of age. ${ }^{135}$ Epictetus uses such military language to encourage young men not to commit suicide, because it would be an abandonment of the place and task to

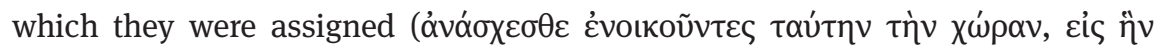

(84e-f), a work Epictetus certainly knew (cf. Long 2002, 158-159); he alludes to it at Epictetus 1.12.23. In the Phaedo, Socrates discusses the immortality of the soul as he faces his own death. As part of a discussion on the immortality of the soul it can also be found in Cicero, Tusc. 1.73. Cf. DNP, s.v. "Schwan".

131 On the nightingale as understood within the ancient encyclopedia cf. DNP, s.v. "Nachtigall”. (Note that it is mentioned at Plato, Phaed. 85a.)

132 Cf. for example Epictetus 1.9.11 on the body; further Epictetus 1.29.16 (Socrates).

133 If the Phaedo is a text to which Epictetus alludes in Epictetus 1.16, then one should note that Socrates compares himself with the swans (who are associated with Apollo [85b]) in respect

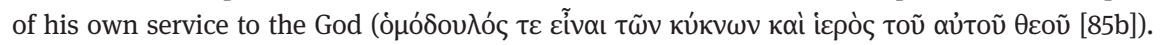
For his service to Apollo, see our discussion of the passage in Plato's Apology in section 6.3.1.1. 134 Cf. also our discussion of Epictetus 1.6 below.

135 That is: as long as it is the will of God that one should remain (cf. Epictetus 1.9.16). 


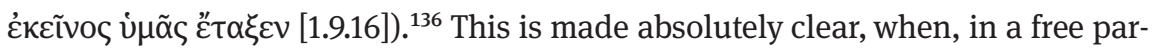
aphrase of what is said in Plato's Apology, ${ }^{137}$ where Socrates rejects the suggestion that he will be allowed to save his life, if he stops with his examination of the people of Athens (cf. Epictetus 1.9.23), Epictetus puts the following words in the mouth of Socrates:

How absurd of you to think that if one of your generals had stationed me in a post ( $\varepsilon \dot{\imath} \mu \varepsilon \dot{v} \nu \varepsilon$

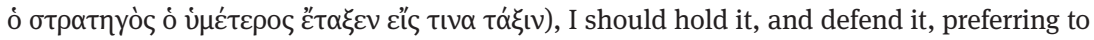

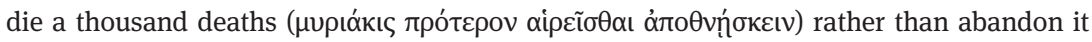

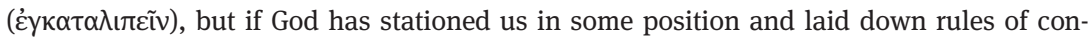

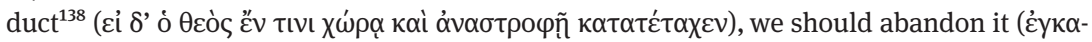

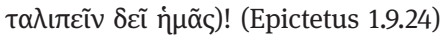

Thus, while the language of remaining in one's post is used to speak about remaining in life, it is precisely language that points to the fact that one has a purpose and a task in life, a vocation, irrespective of age.

Finally, as argued above, it is the fact that Epictetus invites all his hearers to join him (21) which makes it clear that he does not only speak about his own

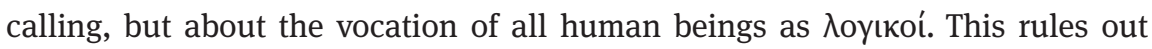
the alternative interpretation.

\subsubsection{Description of the vocation as a sign production}

As to the third point: Epictetus uses language that implies that human beings

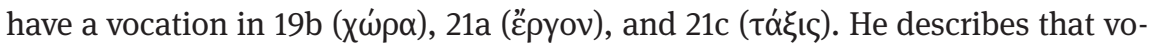
cation in terms of the metaphor of singing a hymn to God (19c, 20b, 20 h). Saying that ن́ $\mu v \varepsilon \tilde{v}$ is a metaphor does not mean that actual singing and praising is excluded. Our notion of sign production captures the sense in which such ú $\mu v \varepsilon i v$ is a human action that is expressive of the insight which is possible because of the human capacity to discern God's providential works and which represents an appropriate response. In these terms, Epictetus here describes the actions in which the human vocation consists as a sign production. Throughout the Discourse, Epictetus has explained the distinctly human capacity to discern God's relation to the world and the human task to articulate this insight and to adopt a stance of

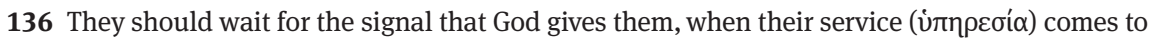
an end (Epictetus 1.9.16).

137 Cf. our discussion of Plato's Apology in section 6.3.1.1 (where Socrates uses the word $\lambda \alpha$ $\tau \rho \varepsilon i ́ \alpha$ [to Apollo] for this task of examining the people of Athens).

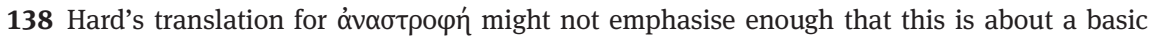
orientation of one's life (cf. Gal 1.13). 
reflective gratitude. He has densely expressed this description in the metaphor of ú $\mu \nu \varepsilon \tilde{v}{ }^{139}$ And it is this sense which our notion of sign production here seeks to capture. With this we are already touching upon the structure of the human vocation in Epictetus, which we will discuss more fully in section 4.5 on Epictetus 1.6.

\subsubsection{Protreptic function}

As to the fourth point: at the end of the Discourse, Epictetus invites all his hearers ( $\pi \alpha \rho \alpha \alpha \lambda \varepsilon \tilde{v}$ ) to join him in the same song (21e). But because he has used the image of singing a song to God as a metaphor that describes in what the human vocation consists, he is effectively inviting his hearers to fulfil their vocation as human beings, to become genuinely human. Protreptic speech seeks to convince hearers of the value of some activity and to win them over, to "turn" them to it. ${ }^{140}$ Often such speech is used to motivate for philosophy (and then it presents philosophy as the highest human aspiration). In Diatr. 1.16.19-21, Epictetus seeks to exhort his hearers to become genuinely human and to fulfil their role in the cosmos. This aspect of the text is very important for the comparison with Rom

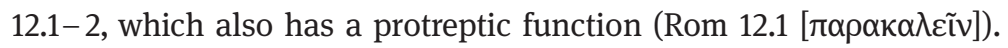

\subsubsection{Conclusion for Epictetus 1.16}

We have thus shown through a close reading of the entire Discourse 1.16, that Epictetus uses the language of 入оуıкó in Epictetus 1.16.20 to refer to the distinctly human capacity on which a human vocation is based. We have seen that he uses a variety of language to express the idea that human beings have a vocation and to describe in what this vocation consists. We have suggested that the notion of sign production captures a crucial aspect of Epictetus' conception of the human vocation. We will substantiate this claim further in the next section, where our analysis of Epictetus 1.6 shows that the human vocation has a certain structure in Epictetus and that sign production is a key part of that structure.

139 The influence of Cleanthes' Hymn to Zeus should not be underestimated (the final lines:

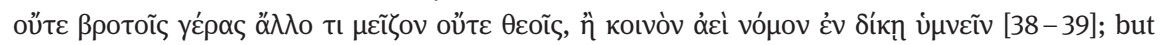
also its emphasis on providence). For text and commentary see Thom 2005. Cf. also the discussion in Forschner 2018, 156-161.

140 Cf. DNP, s.v. "Protreptik”. 


\subsection{The structure of the human vocation: A close reading of Epictetus 1.6}

We have seen that Epictetus is a clear proponent of the idea that there is a human vocation, that is, that there is a certain task in life for human beings, that this task is something which falls to human beings as such, and that this task is assigned to them by God ("Zeus"). It is also clear that this idea is closely linked with the idea of the human endowment with reason. This is what makes humans distinct and gives them the potential for fulfilling that vocation.

Our reading of Epictetus 1.6 will show that there is also a clear structure to that human vocation. ${ }^{141}$ We can describe this structure as consisting of two parts, which we may label "seeing the truth" and "responding appropriately (in sign production)." Both parts are based on the right exercise of human reason. Using their reason rightly, human beings are able to perceive the truth of God in relation to the world and to respond appropriately in actions that reflect this understanding (i.e. in producing signs). In this section, we show that the structure of the human vocation in Epictetus is a sign production based on an understanding of God in relation to the world.

It is important to work out this structure of the human vocation, because we will show in our reading of Romans that Paul not only uses the idea of a human vocation, but that there is a similar structure to the human vocation in Romans (as can be seen particularly in Rom 1.18-32, especially 1.18-21, see section 5.2).

Epictetus 1.6 is once more a text about divine providence, as reflected in the title. ${ }^{142}$ To be more precise, it is a text about the human task to praise divine

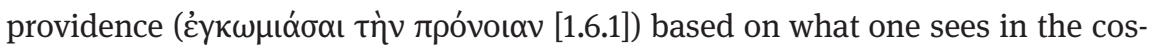

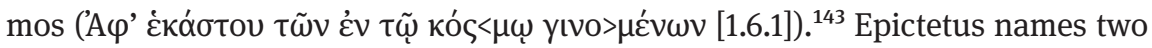
conditions that are needed for this task: the ability to understand the things that

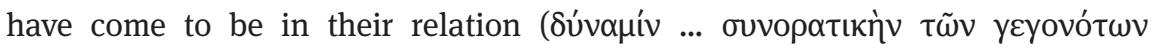

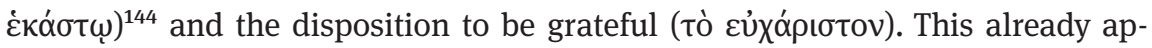

141 This structure can also be seen in the earlier material we have discussed in 2.2.6.3, but in Epictetus 1.6 it is expressed clearly and explicitly.

142 Пврі троvoías.

143 The opening line merely asserts that it is easy to do so, given certain conditions, not that all human beings would be charged to do so. But the context of the entire discourse will support the view as stated here.

144 Hard translates this as "the capacity to view each particular event in relation to the whole". Long 2002, 175 aptly paraphrases this as the "capacit[y] to take a synoptic view". Oldfather renders it as "the faculty of taking a comprehensive view of what has happened in each individual instance.” 
proaches the two parts of the structure of the vocation as described above, the "seeing of the truth" and the "responding appropriately", but the response is named only indirectly, by the disposition which enables it. Epictetus explains that without the former one would not be able to see the usefulness of things

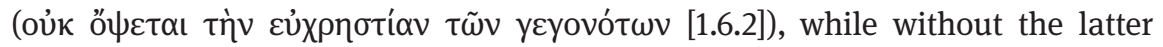
one would still not be moved to respond by giving thanks for them such as

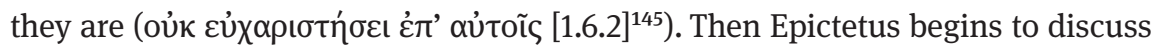
a type of example for his general point that one can discern the usefulness of things, namely the fact that many things in the cosmos are suited to other things in the cosmos ("co-adaption"146). If God (ó $\theta \varepsilon o ̀ \varsigma)$ had made colours, but not given

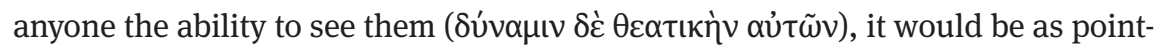
less as, having given the ability to see, he had made nothing which falls under its scope (1.6.3). ${ }^{147}$ This raises the question who is responsible for the "harmonious"

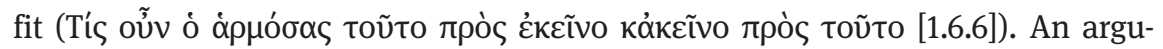
ment from design follows: in the domain of human arts, once we find a sheath perfectly fitting a blade and vice versa, we expect this to be the work of a crafts-

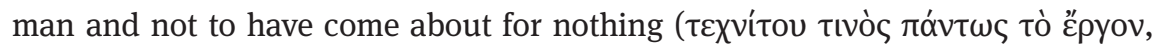

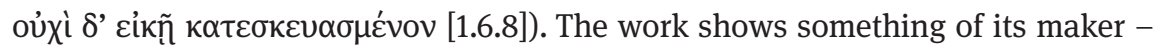
and never should this be more apparent, than when the work is sight and things

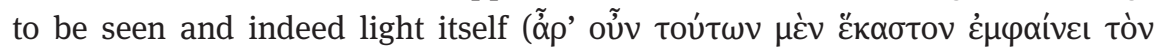

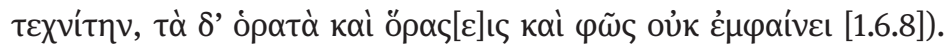

Given that one of the consequences of the inappropriate response of the human beings referred to in Rom 1.18-32 is presented as deviation from the sexual behaviour that Paul assumes to be in line with the created order and its male plus female make-up (Rom 1.26-27), it is interesting to note that Epictetus uses the example of sexual intercourse between male and female and the desire for it

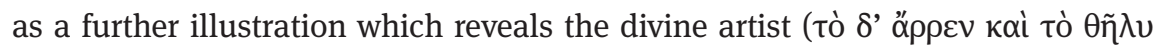

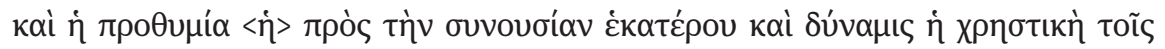

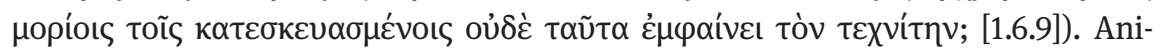
mals also procreate and make use of the way in which they are fittingly made

145 We might expect Epictetus to say that without the former, one would not see what one has to see, but without the latter, even if we had the former, we would still not do the latter. This would be closer to the logic of Rom 1.19-21, where Paul assumes that the people he describes would be able to see, and yet are not responding appropriately. But Epictetus merely considers

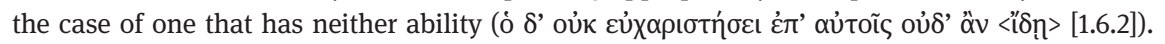
146 For the term see Dobbin 1998, 105.

147 This first example is clearly one of "co-adaption", but it also further elucidates what we have identified as the first part of the structure of the human vocation, namely the human ability to "see". 
for each other, but only humans can understand the order and arrangement intended by their maker. ${ }^{148}$

The reflection on the remarkable constitution of the human mind serves as the final teleological argument for divine providence (1.6.10). Then Epictetus begins to discuss the key difference that emerges with human understanding. Having surveyed features that require divine providence as an explanation, he says: ${ }^{149}$

Well now, is it in us human beings alone that these things ${ }^{150}$ come about? Many, indeed, in

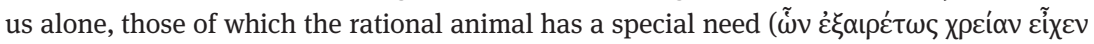

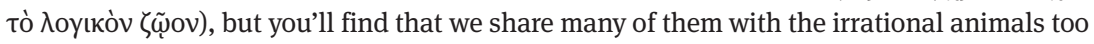

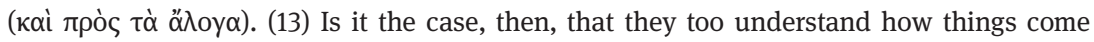

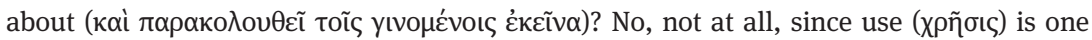
thing and understanding (

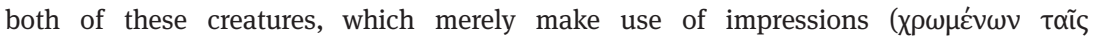

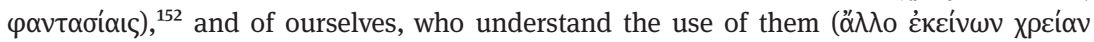

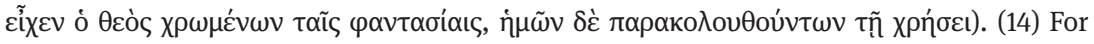
them, it is enough merely to eat, drink, take rest and procreate, and perform such other

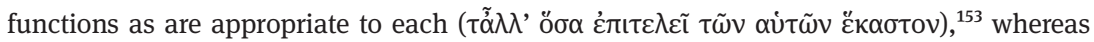
for ourselves, who have been further endowed with the faculty of understanding (oí

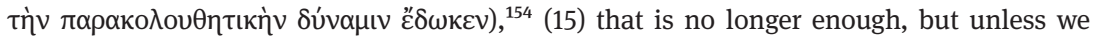
act in a methodical and orderly fashion, and in accordance with our own specific nature

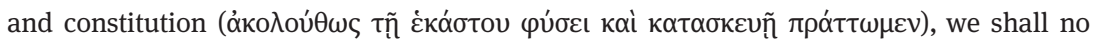

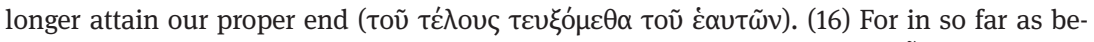

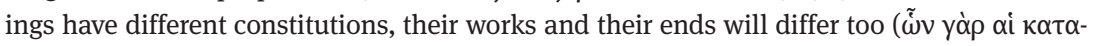

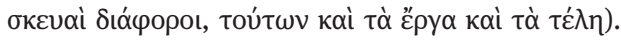

(Epictetus 1.6.12-16) ${ }^{155}$

148 Similarly Cicero, ND 2.128, cf. Dobbin 1998, 105.

149 Epictetus 1.6.12-22 is discussed by Long 2002, 174-175. Dobbin 1998, 102 notes that 1.6.12-22 is a "protreptic section, based on the powers of the mind and the place this makes for man in the natural order."

150 That is, those that require providence as an explanation.

151 Cf. on God having “needs”, Long 2002, 174.

152 For Epictetus' emphasis on the right use of impressions as his "cardinal rule of life" cf. Long 2002, 85.

153 Hard's translation with "function" is not strictly implied in the semantics of the terms translated, but we find it suitable for the import of the passage. Dobbin 2008, for instance, renders

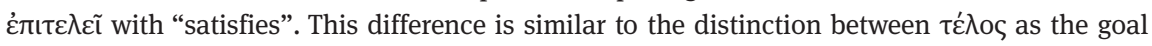
and $\tau \varepsilon ́ \lambda$ os as the termination of something.

154 The Greek formulation is more "personalist” than Hard's rendering suggests (cf. Long 2002, 174). For the mental faculties as God's gift to humans, see Epictetus 1.1.12.

155 Translation R. Hard. 
The world is, for the Stoics, providentially governed and humans have a role in it that requires not just using what their constitution consists in, but understanding it and making use of it according to that understanding. While the other animals all serve their function within the grand cosmic plan in a way that does not require them to follow what is happening, for humans it is different. Their function does not merely require them to follow what is happening. Rather, their being able to understand the rational order of the Stoic cosmos is a crucial element of their human vocation. In Epictetus 1.6.16 we have a clear and explicit instance of the widely shared ancient principle that the constitution of a being is an indication of what they are made for and in what their specific activity consists. ${ }^{156}$ Once more Epictetus uses the idea of an हैpyov ${ }^{157}$ for each being. The formulation "according to one's nature" (1.6.15), reminiscent of one of the variants of the Stoic telos formulae, ${ }^{158}$ indicates the importance of this principle for Stoic thought. ${ }^{159}$ For Epictetus, humans alone have the capacities to not only make use of their mental impressions (1.6.13) as other animals do but also to understand this use:

So where a being's constitution is adapted for use alone, mere use suffices; but where a

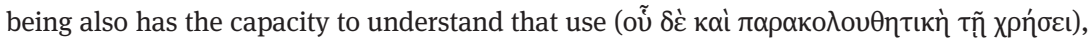
unless that capacity ${ }^{160}$ be properly exercised in addition, he will never attain his end

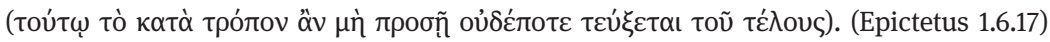

Within the cosmic order, all beings are made for a task or function, ${ }^{161}$ but there is one kind of being, humans, whose purpose is not just to recognise and understand these purposive structures but to articulate them. With this we come to the clearest articulation of the structure of the human vocation:

But God has brought the human race into the world to be a spectator of himself and of his

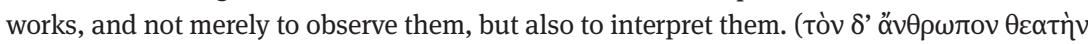

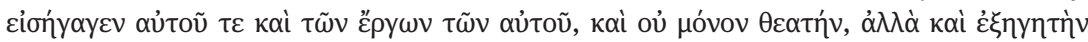

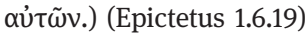

156 Cf. Long 2002, 174: "Nature ... comprises the constitutions of living creatures, making them capable of performing the functions specific to their identities."

157 Dobbin 1998, 109 rightly notes that Epictetus uses a form of the function (हैpyov) argument we have noted above.

158 The material is presented in Rieth 1934. For recent literature see Forschner 2018, 178 n. 74.

159 Cf. Long 2002, 174: “To live 'in accordance with nature' is to play one's specific part within the structure of the cosmic plan."

160 Oldfather translates tò ката̀ тро́лоv as "the principle of propriety".

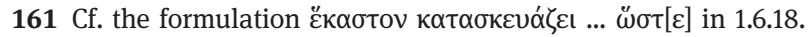


Here we see the two-part structure of the human vocation very clearly. ${ }^{162}$ The purpose of human beings is explained as, first, seeing God and his works ( $\theta \varepsilon \alpha \tau$ 'ो

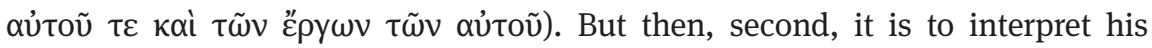

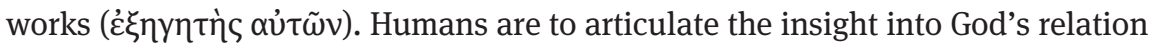
to the world in words, actions and relations that signify their understanding. ${ }^{163}$ They are to produce signs of their understanding of God. Thus, we see here that for Epictetus the human vocation has the structure of a sign production based on the understanding of God.

Epictetus continues to expound these two sides of the human vocation, in terms that make it clear that Epictetus belongs to the wider tradition on the human vocation we have studied in the last chapter:

It is thus shameful (aíxpóv) for a human being to begin and end where the irrational animals do. Rather, he should start off where they do and end where nature ended with regard

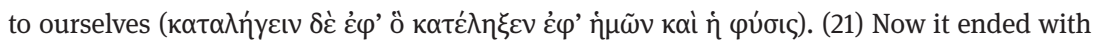
contemplation, and understanding, and a way of life that is in harmony with nature (غ่лì

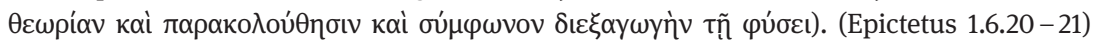

Epictetus acknowledges in 1.6.20 that there is a part of the constitution of the

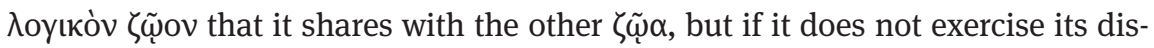
tinct capacity, then it will not reach its goal and fulfilment. This goal is described once more in terms of the two-part structure of the human vocation: it is, first,

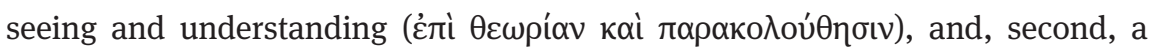
way of life ( $\delta \varepsilon \xi \xi \alpha \omega y \eta$ ) which is in tune with nature as so understood (oú $\mu \varphi \omega v o v$ $\tau \tilde{n} \varphi$ $u ́ \sigma \varepsilon \mathrm{l}){ }^{164}$ The second part is the appropriate response in a sign production. ${ }^{165}$ A life which reflects the understanding of God becomes an interpretation of God's works. Thus, for Epictetus, all of life is involved in a fitting sign production. As Long writes about Epictetus 1.6.12-22:

162 Note that the perspective is on humankind in general (Tòv $\delta^{\prime}$ öv $\theta \rho \omega \pi$ ov [1.6.19]), which corresponds to the consideration of human beings from the standpoint of their definition (cf. tò

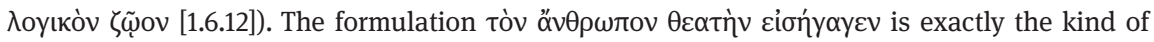
language for the human vocation we have considered in sections 2.2.6.3 and 3.2: God has made human beings and he has made them for a purpose in the cosmos.

163 Dobbin 1998, 109 explains this second part of the vocation as "initiat[ing] others into the

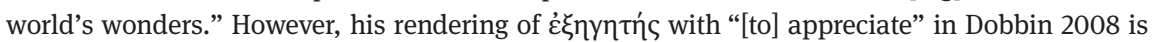
an undertranslation.

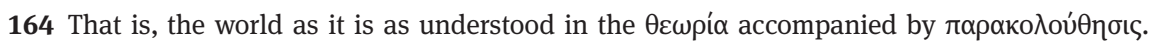
165 This response includes the gratitude which is mentioned at the beginning of this discourse (1.6.1). The element of thanksgiving as characteristic of the human-response side of the vocation is paralleled in Rom 1.21 . 
Epictetus ... make[s] the point that a creature's conformity to, or proper use of, its nature is a service to God. He tells his students to regard the human contribution to that service as "studying and interpreting" God and his works. This is what it is to be a rational animal. ${ }^{166}$

While there is no space to discuss the rest of Epictetus 1.6, where Epictetus offers a kind of "theodicy", ${ }^{167}$ we will conclude this section by quoting Epictetus 1.6.23-25, because its language and motifs show that it belongs to the broader Greco-Roman discourse on the human vocation we have studied in the previous chapter:

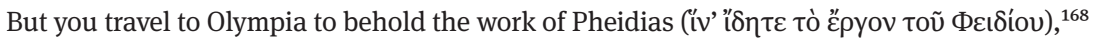

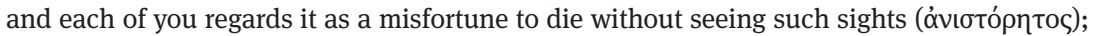
yet when there is not need to travel at all, [but you are already there] ${ }^{169}$ and [he] is present

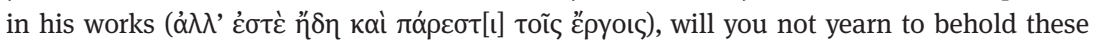

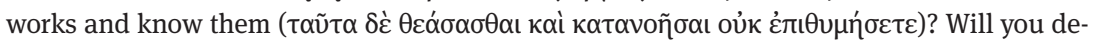

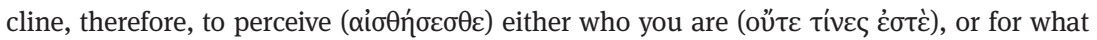

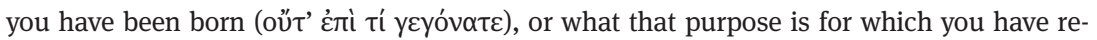

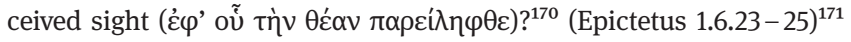

Epictetus exhorts his hearers to perceive their identity as human beings, to understand their purpose, and then to live their vocation. They are to perceive who God is and to produce signs of this understanding, which means that others will be able to perceive who God is in their lives, in their sign production, rather than in the statue produced by Pheidias. As we have seen in the last chapter, the ques-

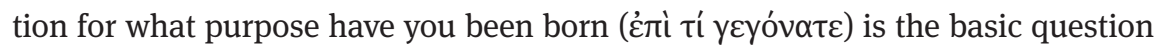
for which, in the Greco-Roman tradition, the human vocation is the answer. And in Romans, Paul, as we shall see, draws on this answer for his own articulation of the genuine human vocation.

166 Long 2002, 175.

167 Dobbin 1998, 103. Especially noteworthy as parallels to Romans would be 1.6.38-40.

168 The statue of Zeus at Olympia. On which see Dio Chrysostom, Or. 12.

169 For this quotation we have used Oldfather's translation, except in the brackets, where we have changed the translation to fit the textual conjecture suggested by Dobbin 1998, 110, which assumes a different Greek text (quoted above).

170 Heinemann 1926, 20 quotes Epictetus 1.6.25.

171 Transl. W. A. Oldfather. 


\subsection{Conclusion}

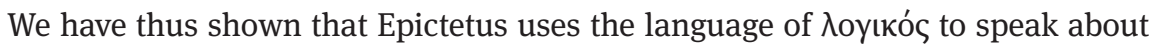
the distinct capacity on which a human calling is based and that there is a twopart structure to this vocation: seeing and understanding God and his providential actions in the world and producing signs of this understanding. We have also seen that Epictetus uses the definition of human beings to speak about genuine humanness. We have demonstrated how Epictetus brings to clear expression broader traditions about what it means to be human by noting how he resonates with the themes we have studied in chapter 3.

All these contextualisations are needed to show how Epictetus 1.16.20-21 is a parallel to Paul's reason language in Rom 12.1. In Epictetus, reason language is used to speak about a genuinely human calling. The next chapters show how the same holds true for Romans, even as there are significant differences as well. 